\title{
Research on the Mechanisms of Plant Enrichment and Detoxification of Cadmium
}

\author{
Gui-Li Yang ${ }^{1,2}{ }^{\oplus}$, Meng-Meng Zheng ${ }^{1}$, Ai-Juan Tan ${ }^{1}$, Yu-Ting Liu ${ }^{1}$, Dan Feng ${ }^{1}$ and Shi-Ming Lv ${ }^{3, *}$ \\ 1 College of Life Sciences, Guizhou University, Guiyang 550025, China; glyang3@gzu.edu.cn (G.-L.Y.); \\ zmm18073198235@163.com (M.-M.Z.); ajtan@gzu.edu.cn (A.-J.T.); liuyut90@163.com (Y.-T.L.); \\ fengdan1901@163.com (D.F.) \\ 2 State Key Laboratory of Environmental Geochemistry, Institute of Geochemistry, Chinese Academy of \\ Sciences, Guiyang 550081, China \\ 3 College of Animal Science, Guizhou University, Guiyang 550025, China \\ * Correspondence: lvlvsm@163.com; Tel.: +86-1376-513-6919
}

check for updates

Citation: Yang, G.-L.; Zheng, M.-M.; Tan, A.-J.; Liu, Y.-T.; Feng, D.; Lv, S.-M. Research on the Mechanisms of Plant Enrichment and Detoxification of Cadmium. Biology 2021, 10, 544. https://doi.org/10.3390/ biology10060544

Academic Editor: Stefano Loppi

Received: 13 April 2021

Accepted: 11 June 2021

Published: 17 June 2021

Publisher's Note: MDPI stays neutral with regard to jurisdictional claims in published maps and institutional affiliations.

Copyright: (c) 2021 by the authors. Licensee MDPI, Basel, Switzerland. This article is an open access article distributed under the terms and conditions of the Creative Commons Attribution (CC BY) license (https:/ / creativecommons.org/licenses/by/ $4.0 /)$.
Simple Summary: Generally, plants undergo a series of oxidative damage and even die after being stressed by cadmium (Cd). Recently, numerous studies about hyperaccumulators that can tolerate and enrich cadmium in the environment have been reported, revealing its potential in restoration of heavy metal pollution. However, there is a lack of systemic understanding of the mechanisms of $\mathrm{Cd}$ accumulation and detoxification by hyperaccumulators. Therefore, the purpose of this review is to investigate how these plants absorb, transport, and distribute Cd. The role of plant roots, compartmentalization, chelation, antioxidants, stress, and osmotic adjustment in bioaccumulation of $\mathrm{Cd}$ are comprehensively discussed. This review contributes to further understanding the mechanisms of plant enrichment and detoxification of heavy metals.

Abstract: The heavy metal cadmium (Cd), as one of the major environmentally toxic pollutants, has serious impacts on the growth, development, and physiological functions of plants and animals, leading to deterioration of environmental quality and threats to human health. Research on how plants absorb and transport $\mathrm{Cd}$, as well as its enrichment and detoxification mechanisms, is of great significance to the development of phytoremediation technologies for ecological and environmental management. This article summarises the research progress on the enrichment of heavy metal cadmium in plants in recent years, including the uptake, transport, and accumulation of $\mathrm{Cd}$ in plants. The role of plant roots, compartmentalisation, chelation, antioxidation, stress, and osmotic adjustment in the process of plant $\mathrm{Cd}$ enrichment are discussed. Finally, problems are proposed to provide a more comprehensive theoretical basis for the further application of phytoremediation technology in the field of heavy metal pollution.

Keywords: heavy metals; cadmium pollution; phytoremediation; enrichment mechanisms

\section{Introduction}

With the acceleration of modern industrialisation, the problem of heavy metal pollution has become increasingly prominent [1-3]. At present, nearly 20 million hectares of farmland in China are polluted by heavy metals such as mercury, cadmium (Cd), and lead [4]. In 2015, a soil research survey showed that $16.1 \%$ of China's soil and $19.4 \%$ of agricultural soil were polluted by heavy metals, of which cadmium pollution $(7.0 \%)$ was the most serious. The Ministry of Ecology and Environment of China announced in 2019 that cadmium was still the main heavy metal pollutant in the soil [5-7].

$\mathrm{Cd}$ is a toxic heavy metal that can exist in soil, water, and the atmosphere in various forms $[8,9] . \mathrm{Cd}^{0}$ in the atmosphere can become immobilised by combining with iron (Fe) and manganese $(\mathrm{Mn})$ oxides and can also be atmospherically deposited on rain, dust, and snow [10]. $\mathrm{Cd}$ in soil and water is usually in an exchangeable state $\left(\mathrm{CdCl}_{2}\right.$ and other 
water-soluble forms), carbonate-bound state (such as $\mathrm{CdHCO}_{3}{ }^{-}$), organic-bound state (combined with organic matter in the environment), or residual state (such as $\mathrm{H}_{2} \mathrm{SiO}_{3}$ ) [8]. $\mathrm{Cd}$ in plants is mainly in an inorganic form (such as chloride), Cd-phosphate complex (such as $\mathrm{CdHPO}_{4}$ ), and in the form of binding with pectin and protein. These associations have been confirmed by studies of Echinodorus osiris Rataj [11], Myriophyllum aquaticum [12], and Raphanus sativus L. [13].

Cd can impair animal and plant growth and human health [14,15]. The growth of radish was significantly inhibited when grown in soil containing with $5.0 \mathrm{mg} \mathrm{kg}^{-1}$ (dry weight, DW) Cd [13]. The biomass, root length, plant height, and the chlorophyll of Ceratopteris pteridoides were reduced when exposed to water containing $20 \mu \mathrm{M} \mathrm{Cd}$ [16]. The length and dry weight of marigold were reduced when grown in soil containing $50 \mathrm{mg} \mathrm{kg}^{-1}$ (DW) Cd [17]. Cd from the soil is taken up by crop plants through a migration process and enters the food chain $[18,19]$. Cd is ingested into the human body through diet and deposited in tissues. Cd-related liver and brain toxicity has been described in humans ingesting a diet containing $1 \mathrm{mg} \mathrm{kg}^{-1}$ (body weight)/day or $70 \mathrm{mg} /$ day Cd, respectively [14]. Cadmium can also cause damage to the liver and brain, leading to high blood pressure and even cancer [14,20-23].

As an abiotic stress factor, $\mathrm{Cd}$ can affect the growth and development of plants to varying degrees [14]. When $\mathrm{Cd}$ in the environment exceeds a certain concentration, it will stimulate oxidative stress in plants, induce lipid peroxidation, and increase the accumulation of reactive oxygen species (ROS), leading to oxidative damage [20,24-26]. In addition, $\mathrm{Cd}$ can also cause slower plant growth, decreased chlorophyll content, yellow leaves, and slower photosynthetic rate. Therefore, the growth, development, and physiological and biochemical effects of plants are affected, and high $\mathrm{Cd}$ concentration can even cause plant death $[16,27,28]$.

Different plants have different tolerances to $\mathrm{Cd}$. Radish biomass was reduced in the presence of $5.0 \mathrm{mg} \mathrm{kg}^{-1}$ (DW) Cd treatment [13]. However, no change in the biomass of Lantana camara L. (a hyperaccumulator) has been observed when the Cd lower than $100 \mathrm{mg} \mathrm{kg}^{-1}$ (DW), and chlorophyll does not decrease even exposure with $200 \mathrm{mg} \mathrm{kg}^{-1}$ (DW) Cd [29]. Among them, hyperaccumulators can over-absorb heavy metals and transport and retain them in the shoots [30-32]. Plant species that contain more than $1000 \mu \mathrm{g}$ of heavy metal per gram (DW) are called hyperaccumulators [26]. Hyperaccumulators have been reported include Echinodorus Osiris Rataj [11], Youngia japonica (L.) DC [33], Ceratopteris pteridoides [16], Lantana camara L. [29], Pterocypsela laciniata [34], Sedum alfredii [35], Microsorum pteropus [36], Taraxacum ohwianum Kitam. [37], Siegesbeckia orientalis L. [38], Thlaspi caerulescens [39], and Arabidopsis [40]. Compared with normal plants, hyperaccumulators can not only maintain normal physiological function in a high-concentration heavy metal environment but can also absorb heavy metals to enrich them [12,38]. Compared with physical and chemical methods to control Cd pollution, the bioremediation method using hyperaccumulators has the advantages of low cost and no secondary pollution [31,41,42]. The roots of plants absorb $\mathrm{Cd}$ from the environment and then transport it to other tissues through transporters and enrich it inside the plant, thereby limiting the toxicity of $\mathrm{Cd}$ to plants and reducing the pollution of $\mathrm{Cd}$ in the environment. Therefore, hyperaccumulators show great potential in repairing $\mathrm{Cd}$ pollution and have become a research hotspot in the field of heavy metal pollution.

Several published studies focused on the absorption and transport of $\mathrm{Cd}$ and the detoxification mechanisms in plants. Shahid et al. [8] reviewed the bioavailability, absorption, transport, and detoxification of $\mathrm{Cd}$ in plants in the soil. Ismael et al. [43] summarized the toxicity of $\mathrm{Cd}$ to plants and discussed how selenium (Se) reduces the toxic effects of $\mathrm{Cd}$ on plants. Riaz et al. [44] further investigated the role of Se and silicon ( $\mathrm{Si}$ ) in reducing the toxicity of $\mathrm{Cd}$ in plants and clarified the potential detoxification mechanism of Se and Si to plants. Li et al. [45] summarized the hyperaccumulators reported in China and their tolerance and the effect of $\mathrm{Cd}$ on various aspects. However, no study has comprehensively 
reviewed the absorption, transport, and distribution of $\mathrm{Cd}$ in plants or the mechanisms of enrichment and detoxification of $\mathrm{Cd}$ by plants.

This article reviews the studies on the uptake, transport, distribution, and enrichment mechanisms of heavy metal $\mathrm{Cd}$ in plants and further elucidates the mechanisms of $\mathrm{Cd}$ enrichment in plants to promote the advantages of hyperaccumulators in phytoremediation technology for $\mathrm{Cd}$ pollution.

\section{Uptake, Transport, and Distribution of Cd in Plants}

2.1. Pathways of Cd Uptake by Plants

The main way for $\mathrm{Cd}$ to enter plants is to be taken up from the soil or water through the roots of the plant, and it can also be taken up from the atmosphere through the leaves of the plant $[46,47]$. The uptake of $\mathrm{Cd}$ by the roots is mainly divided into two steps. First, $\mathrm{Cd}$ interacts electrostatically with plant root secretions and negatively charged carboxyl groups on the root cell wall, thereby adsorbing onto plant roots [48,49]. This step is spontaneous and rapid. Then, the $\mathrm{Cd}$ adsorbed by the roots passes through the plant cortex by plasma membrane transporters such as natural resistance-associated macrophage protein and is finally absorbed by the plant root cells. This step is achieved by the high mobility and water solubility of $\mathrm{Cd}$. Studies have shown that, as the $\mathrm{Cd}$ concentration in the environment increases, the $\mathrm{Cd}$ content in plants also increases, but the rate of $\mathrm{Cd}$ transport from plant roots to shoots decreases [50]. $\mathrm{Cd}^{2+}$ in the environment is absorbed into plants through competition with metal cations such as $\mathrm{Cu}^{2+}, \mathrm{Fe}^{2+}, \mathrm{Mn}^{2+}$, and $\mathrm{Zn}^{2+}$. Therefore, the higher the $\mathrm{Cd}$ concentration in the environment, the greater its competitive advantage [51-53]. Cd enters the cell through active transport at low concentrations and passive transport at high $\mathrm{Cd}$ concentrations (Figure 1). In addition, the content of heavy metal particles in the air in polluted areas is significantly related to the content of heavy metals in plant leaves, which is speculated to be related to atmospheric deposition [54,55]. Heavy metal particles in the air can be deposited on the surface of plants by rain and dust and are directly absorbed into the plant body through the stomata of the leaf epidermis or interact with the cuticle of the epidermis to be absorbed by the plant [56,57]. Although there are two uptake pathways, root absorption is the main pathway of uptake.

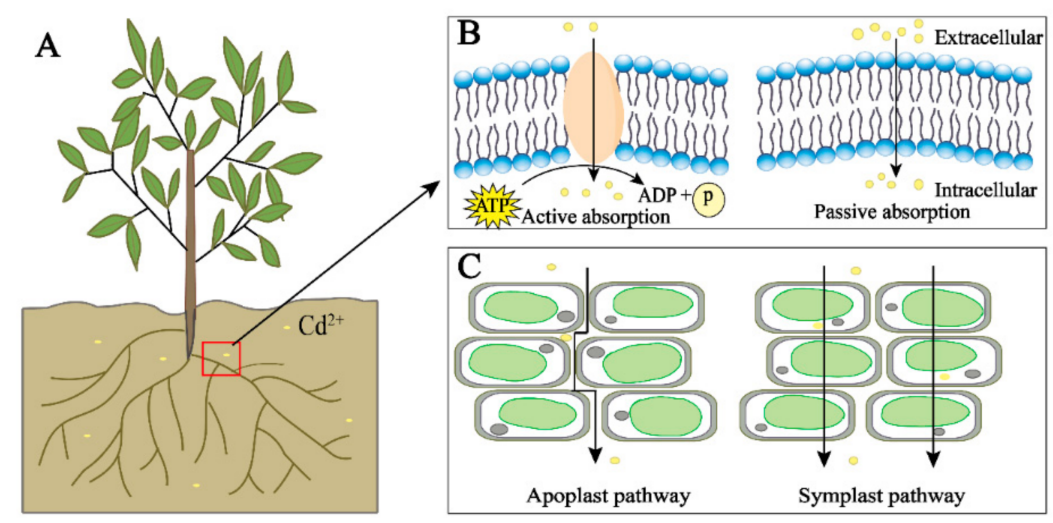

Figure 1. The root uptake of cadmium in plants. $\mathrm{Cd}$ (yellow) in the environment can enter plants through plant roots (A); when the concentration of Cd is low, ATP is consumed for active transport, and when the concentration is high, it directly enters cells for passive absorption (B); Cd is transported between cells by the apoplast and symplast pathways (C).

\subsection{Plant Transport of $\mathrm{Cd}$ and Involved Transporters}

There are two main transport pathways of $\mathrm{Cd}$ in plants: the symplast and apoplast pathways. The apoplast pathway is where $\mathrm{Cd}$ is transported through the gap between plant cell walls and the gap between the cell wall and the plasma membrane; the symplast pathway is where Cd is transported into the cell through the transporters and then transported between the cells through the plasmodesmata (Figure 1C) [56]. Cd in the 
environment is actively or passively absorbed by plants, first loaded in the root xylem, and then further transported through the xylem to the plant shoots [58,59]. In plants, Cd can also be efficiently transported from senescent tissues to young tissues through the phloem to facilitate the transport and redistribution of $\mathrm{Cd}$ in plants [30].

Plants require the participation of transporters in the process of uptake and transport of Cd, which mainly include yellow-stripe 1-like transporter (YSL) [60,61], zinc-regulated and iron-regulated transporter-like protein (Zrt, Irt-like, ZIP) [62,63], heavy metal ATPase (HMA) [64,65], natural resistance-associated macrophage protein (NRAMP) [66,67], cadmium accumulation in leaf 1 (CAL1) [68,69], and ATP binding cassette transporters $(\mathrm{ABC})$ [70]. Among them, the YSL protein is considered to play an important role in the process of plant transportation of $\mathrm{Cd}^{2+}, \mathrm{Fe}^{2+}, \mathrm{Fe}^{3+}, \mathrm{Ni}^{2+}, \mathrm{Zn}^{2+}$, and other metal chelates, such as the chelate formed by $\mathrm{Fe}^{3+}$ and nicotianamine, and the chelate formed by $\mathrm{Fe}^{3+}$ and phytosiderophores. The YSL protein is an oligopeptide transporter involved in the transport of metal-nicotianamine complexes [60,61]. The YSL protein (YS1) of corn's main function is to transport the Fe-phytosiderophore complex needed for corn growth into corn root epidermal cells [71,72]. If the YSL gene of maize is mutated, it will lead to the loss of part of the transport function of maize, which is manifested as leaf interveinal chlorosis, so it is named the "yellow stripe" transporter [73]. Das et al. [74] cloned the BjYSL gene from the Cd hyperaccumulator, Brassica juncea, and BjYSL6.1, which was specifically upregulated in shoots after $\mathrm{Cd}$ treatment, indicating that the YSL protein is involved in the transport of $\mathrm{Cd}$ from roots to shoots. Subsequently, Wang et al. [75] overexpressed the BjYSL7 gene in tobacco and found that the Cd content in the BjYSL7 overexpression plants was significantly higher than that of the wild type, the roots were longer, and the root hair development was better, further proving that the BjYSL protein participates in the transport of Cd to shoots. SnYSL3 was also cloned in another Cd hyperaccumulator, Solanum nigrum, and overexpressed in the model plant Arabidopsis thaliana. The study found that SnYSL3 was expressed in the vascular tissue and epidermal cells of Arabidopsis roots and stems. SnYSL3 expression was significantly upregulated after treatment with $100 \mu \mathrm{M} \mathrm{CdCl}_{2}$ for $24 \mathrm{~h}$, and the Cd transport rate of overexpressed SnYSL3 plants was significantly higher than that of the wild type, which proved that the YSL protein is involved in the uptake and transport of $\mathrm{Cd}$ in plants [76]. Although many studies have shown that the YSL protein is involved in the transport of $\mathrm{Cd}$, there are few studies on YSL protein as a whole. In particular, the structure of the YSL transporter is still unclear.

The ZIP family is responsible for the uptake and transport of essential and nonessential metal ions in plants and participates in the uptake and transport of a variety of divalent cations, including $\mathrm{Cd}^{2+}[62,77]$. Most ZIP proteins have eight transmembrane domains, the amino and carboxyl ends of which are located outside the cell [62,78]. The area between the third and fourth domains is called the "variable domain". In the variable domain, there is a histidine-rich domain that is considered to be part of the cytoplasm and is a metal ion binding site [79]. The mutants lacking this domain have $\mathrm{Cd}$ transport ability, and the mutants lacking part of the domain have enhanced transport activity, indicating that the histidine-rich domain is related to Cd transport activity [79]. Grotz et al. [63] cloned ZIP1, ZIP2, and ZIP3 from Arabidopsis thaliana and expressed the ZIP genes in zrt1 and $z r t 2$ mutants ( $z r t 1$ and $z r t 2$ mutants were inhibited in zinc uptake due to lack of high-and low-affinity zinc uptake systems), and the uptake of zinc by yeast was increased after the expression of ZIP1 and ZIP3 genes. In addition, $\mathrm{Cd}$ can inhibit zinc uptake mediated by ZIP1, ZIP2, and ZIP3, indicating that Cd can also be taken up from the soil by ZIP transporters and be transported to plants as a substrate of ZIP transporters. Similarly, VsRIT1 is a ZIP gene cloned from Vicia sativa. After VsRIT1 is expressed in Arabidopsis and yeast, the transport and accumulation of $\mathrm{Cd}$ is significantly increased, while the tolerance of $\mathrm{Cd}$ in yeast is reduced [80]. This is consistent with the increase in Cd accumulation after BcZIP2 expression in Brassica campestris L. ssp. Chinensis [81], which fully proves that ZIP protein is involved in the process of Cd uptake and transport. 
The HMA protein, also called $\mathrm{P}_{1 \mathrm{~B}}$-ATPase, belongs to the P-type ATPase gene family. The HMA transporter has eight transmembrane helices. There is a CPX/SPC motif on the sixth, larger transmembrane helix, and it is speculated that there are metal binding domains at the N-terminus and/or C-terminus [65,82,83]. According to the difference in binding specificity with the substrate, the HMA transporter can be divided into two subgroups: the $\mathrm{Cu} / \mathrm{Ag}$ subgroup, and $\mathrm{Zn} / \mathrm{Co} / \mathrm{Cd} / \mathrm{Pb}$ subgroup [50]. Rice [64], Populus tomentosa Carr. [84], Brassica juncea [85] and Arabidopsis thaliana [86], and many other hyperaccumulators contain the $\mathrm{HMA} \mathrm{Zn} / \mathrm{Co} / \mathrm{Cd} / \mathrm{Pb}$ subgroup. A repeating region near the C-terminus in Brassica juncea is named BjHMA4R [85]. Cloning and expressing BjHMA4R in yeast is beneficial in improving the tolerance to $\mathrm{Cd}$ and the accumulation of $\mathrm{Cd}$, which was confirmed by the analysis of the C-terminal region of OsHMA3 transgenic Arabidopsis thaliana [86]. Arabidopsis hma4 mutants and hma2hma4 mutants were more sensitive to $\mathrm{Cd}$ and had significantly inhibited root growth. The hma2hma4 mutant increased Cd accumulation in the roots, and the transport of $\mathrm{Cd}$ from roots to shoots was 2-3\% of the wild type [87], which is consistent with the result that the Athma4 mutant transport rate decreased by at least 50\% [88]. In the two overexpressed HMA Arabidopsis lines modified by the $35 \mathrm{~S}$ strong promoter, $\mathrm{Cd}$ accumulation in rosette leaves was three times that of the wild type. The $\mathrm{Cd}$ concentration in the roots and shoots of the overexpressed rice OsHMA3 strain was higher than that of the control group, and the roots showed higher $\mathrm{Cd}$ content at low and high $\mathrm{Cd}$ culture concentrations. This is consistent with the conclusion that $\mathrm{Cd}$ accumulation in PtoHMA5 transgenic tobacco leaves increased by $25.04 \%$ and the transport rate increased by 16.7-43.25\% [84]. In addition, immunostaining studies have shown that cucumber CsHMA3 and CsHMA4 were expressed in the tonoplast and plasma membrane of cucumber root cells, respectively [89], and cucumber CsHMA3 and CsHMA4 were expressed in the vacuole membrane and plasma membrane of cucumber root cells, respectively, indicating that HMA protein exists in the root cell membrane and tonoplast membrane and plays an important role in the uptake of $\mathrm{Cd}$ from roots and the transport of $\mathrm{Cd}$ to shoots.

The NRAMP protein is a family of membrane-integral transport proteins. NRAMP1 is the first protein discovered in the NRAMP family and participates in the process of macrophage resistance to bacterial infection by transporting $\mathrm{Fe}^{2+}$ [90]. Sedum alfredii SaNRAMP6 [91] is expressed on the plasma membrane of epidermal cell protoplasts. After heterologous expression in yeast, the $\mathrm{Cd}$ content increased, and the same was true after transfer to Arabidopsis. This is consistent with the increase in Cd concentration in roots, stems, leaves, and whole plants after TtNRAMP6 overexpression in Arabidopsis thaliana [92], and the sensitivity to $\mathrm{Cd}$ and the increase in Cd content after the heterologous expression of TcNRAMP3 in Thlaspi caerulescens [93]. In addition, Wu et al. [94] found that HvNRAMP5 was mainly expressed in root epidermal cells, and the expression of the root tip was higher than that of the root base. Further research by Tiwari et al. [95] showed that the root endothelial layer and pericyll cells were the main sites of rice OsNRAMP1 expression in Arabidopsis, and NcNRAMP1 has been shown to participate in the process of $\mathrm{Cd}$ passing through the endothelial plasma membrane [66]. The presence of NRAMP protein is beneficial to the xylem parenchyma of plant roots to load $\mathrm{Cd}$ and transport it to young plant parts in the phloem [30].

In the process of heavy metal uptake and transport, the participation of transporters and their importance (Table 1) has received extensive attention from scholars. Many transporters, such as YSL, ZIP, HMA, and NRAMP, that participate in the uptake and transport of $\mathrm{Cd}$ have been studied. However, the molecular mechanism of the specific binding of the abovementioned transporter to metal ions and the relationship between the structure and function of the transporter are still unclear. These are essential in elucidating the mechanisms of $\mathrm{Cd}$ uptake and transport in plants. 
Table 1. Statistics of transporters in different plants.

\begin{tabular}{|c|c|c|c|}
\hline Species & Transporter & Metal Ions & Refs \\
\hline Brassica juncea & $\begin{array}{c}\text { BjYSLs BjNRAMPs } \\
\text { BjYSL7 } \\
\text { BjHMA4 }\end{array}$ & $\begin{aligned} & \mathrm{Cd}^{2+} \\
\mathrm{Fe}^{2+}, & \mathrm{Cd}^{2+}, \mathrm{Ni}^{2+} \\
\mathrm{Cd}^{2+} & \end{aligned}$ & $\begin{array}{l}{[74]} \\
{[75]} \\
{[85]}\end{array}$ \\
\hline Arabidopsis & $\begin{array}{c}\text { AtHMA4 } \\
\text { HMA2, HMA4 } \\
\text { ZIP1, ZIP2, ZIP3, ZIP4 }\end{array}$ & $\begin{array}{c}\mathrm{Zn}^{2+}, \mathrm{Cd}^{2+} \\
\mathrm{Cd}^{2+} \\
\mathrm{Zn}^{2+}\end{array}$ & $\begin{array}{l}{[88]} \\
{[88]} \\
{[63]}\end{array}$ \\
\hline Arabidopsis halleri & AhZIP6 & $\mathrm{Zn}^{2+}, \mathrm{Cd}^{2+}$ & [96] \\
\hline Oryza sativa $\mathrm{L}$. & $\begin{array}{c}\text { OsHMA1, OsHMA 2, } \\
\text { OsHMA3 } \\
\text { OsNRAMP1, OsNRAMP5 } \\
\text { OsZIP1, OsZIP3 }\end{array}$ & $\begin{array}{c}\mathrm{Zn}^{2+}, \mathrm{Cd}^{2+} \\
\mathrm{Cd}^{2+}, \mathrm{As}^{3+}, \mathrm{Mn}^{2+} \\
\mathrm{Cu}^{2+}, \mathrm{Zn}^{2+}, \mathrm{Cd}^{2+}\end{array}$ & $\begin{array}{c}{[64,86,97,98]} \\
{[63,95,97]} \\
{[99,100]}\end{array}$ \\
\hline Thlaspi caerulescens & $\begin{array}{c}\text { TcNRAMP3 } \\
\text { ZNT1, ZNT5 ZIP }\end{array}$ & $\begin{array}{l}\mathrm{Fe} 3+, \mathrm{Cd}^{2+} \\
\mathrm{Zn}^{2+}, \mathrm{Cd}^{2+}\end{array}$ & $\begin{array}{c}{[93]} \\
{[101]}\end{array}$ \\
\hline Sedum alfredii & SaNRAMP6 & $\mathrm{Cd}^{2+}$ & [91] \\
\hline Sedum plumbizincicola & SpHMA1, SpHMA3 & $\mathrm{Cd}^{2+}$ & {$[35,102]$} \\
\hline Brassica campestris ssp. chinensis & $\begin{array}{c}\text { HMA2, HMA4, BcGSTU } \\
\text { BcNRAMP5 } \\
\text { BcIRT1, BcZIP2 }\end{array}$ & $\begin{array}{c}\mathrm{Cd}^{2+} \\
\mathrm{Cd}^{2+} \\
\mathrm{Cd}^{2+}, \mathrm{Mn}^{2+}, \mathrm{Zn}^{2+}, \mathrm{Fe}^{2+} \\
\end{array}$ & $\begin{array}{c}{[81,103]} \\
{[104]} \\
{[105]}\end{array}$ \\
\hline Hordeum vulgare & $\begin{array}{c}\text { HvNRAMP5 } \\
\text { HvYS1 }\end{array}$ & $\begin{array}{c}\mathrm{Mn}^{2+}, \mathrm{Cd}^{2+} \\
\mathrm{Fe} 3+\end{array}$ & $\begin{array}{c}{[94]} \\
{[106]}\end{array}$ \\
\hline cucumber & CsHMA3, CsHMA4 & $\mathrm{Pb}^{2+}, \mathrm{Zn}^{2+}, \mathrm{Cd}^{2+}$ & [89] \\
\hline Solanum nigrum & SnYSL3 & $\mathrm{Fe}^{2+}, \mathrm{Cu}^{2+}, \mathrm{Zn}^{2+}, \mathrm{Cd}^{2+}$ & [76] \\
\hline Populus tomentosa Carr. & PtoHMA5 & $\mathrm{Cd}^{2+}$ & [84] \\
\hline Brassica napus L. & BnaHMA4c & $\mathrm{Cd}^{2+}$ & {$[107]$} \\
\hline Vicia sativa & VsRIT1 & $\mathrm{Cd}^{2+}, \mathrm{Fe}(\mathrm{EDTA}-\mathrm{Fe}), \mathrm{Zn}^{2+}$ & [80] \\
\hline Triticum turgidum L. ssp. turgidum & TtNRAMP6 & $\mathrm{Cd}^{2+}$ & [92] \\
\hline Triticum polonicum L. & TpNRAMP5 & $\mathrm{Cd}^{2+}, \mathrm{Co}^{2+}, \mathrm{Mn}^{2+}$ & {$[108]$} \\
\hline Nicotiana tabacum & $\begin{array}{c}\text { NtZIP1 } \\
\text { NtNRAMP5 }\end{array}$ & $\begin{array}{l}\mathrm{Cd}^{2+}, \mathrm{Zn}^{2+} \\
\mathrm{Mn}^{2+}, \mathrm{Cd}^{2+}\end{array}$ & $\begin{array}{c}{[50]} \\
{[109]}\end{array}$ \\
\hline
\end{tabular}

Refs: references.

\subsection{Distribution and Subcellular Distribution of Cd in Plants}

Heavy metals such as $\mathrm{Cd}$ are absorbed from the environment by these transporters into plant roots and then transported to shoots, where they are distributed to various tissues of the plant. The distribution of $\mathrm{Cd}$ in plants varies according to plant species and varieties (Table 2). In different types of daily vegetables, the order of $\mathrm{Cd}$ accumulation capacity (which is termed the bioconcentration factor, corresponding to the ratio of the $\mathrm{Cd}$ content in vegetables and soil) is leafy vegetables $(18.9 \%)>$ solanum fruits $(4.9 \%)>$ legumes $(2.1 \%)>$ melons $(1.6 \%)>$ tubers $(1.4 \%)$ [110]. The distribution of $\mathrm{Cd}$ in different plant tissues (Table 2) usually shows that the accumulation of $\mathrm{Cd}$ in the roots of plants is the largest, and the accumulation of $\mathrm{Cd}$ in shoots is less than that in roots, which is related to the retention of $\mathrm{Cd}$ by plant roots [88]. In Monashree's research on Ceratopteris pteridoides [16], the accumulation of $\mathrm{Cd}$ is as follows: $\operatorname{root}\left(1316.34 \mathrm{mg} \mathrm{kg}^{-1}, \mathrm{DW}\right)>$ leaf $\left(191.38 \mathrm{mg} \mathrm{kg}^{-1}, \mathrm{DW}\right)>\operatorname{stem}\left(186.19 \mathrm{mg} \mathrm{kg}^{-1}, \mathrm{DW}\right)$. The results are similar to those for the Cd hyperaccumulator, Microsorum pteropus [111]. In another Camellia sinensis study, the accumulation of $\mathrm{Cd}$ was shown as stem $\left(0.52 \mathrm{mg} \mathrm{kg}^{-1}, \mathrm{DW}\right)>$ leaves $\left(0.12 \mathrm{mg} \mathrm{kg}^{-1}\right.$, DW) $>$ new shoots $\left(0.06 \mathrm{mg} \mathrm{kg}^{-1}\right.$, DW) [112]. Similar results appeared in soybeans [113]. In a study on tobacco [114] and Solanum nigrum [115], the content of Cd in leaves was 
significantly higher than in roots and stems. It is speculated that the $\mathrm{Cd}$ in these plants is mainly concentrated in the roots at low Cd concentrations. When the environmental Cd content increases, the uptake and distribution mode of the plant is adjusted, the Cd uptake of the whole plant increases, and $\mathrm{Cd}$ is enriched in the leaves. The $\mathrm{Cd}$ concentration in the shoots and roots of Youngia japonica (L.) DC under the treatments of $10 \mathrm{mg} \mathrm{kg}^{-1} \mathrm{Cd}(\mathrm{DW})$ and $30 \mathrm{mg} \mathrm{kg}^{-1}$ (DW) Cd in soil was similar. Under $120 \mathrm{mg} \mathrm{kg}^{-1}$ (DW) Cd treatment in soil, the $\mathrm{Cd}$ concentration of the shoots reached $314.29 \mathrm{mg} \mathrm{kg}^{-1}$ (DW), which was significantly higher than that of roots $\left(252.51 \mathrm{mg} \mathrm{kg}^{-1}, \mathrm{DW}\right)$ [33], which also supports this hypothesis.

Table 2. Distribution and subcellular distribution of cadmium in different plants.

\begin{tabular}{|c|c|c|c|c|c|c|c|c|c|c|}
\hline \multirow{2}{*}{ Plant } & \multicolumn{4}{|c|}{ Distribution (mg kg-1, DW) } & \multicolumn{3}{|c|}{ SD (\%) } & \multirow{2}{*}{ BCF } & \multirow{2}{*}{ TF } & \multirow{2}{*}{ Refs } \\
\hline & Root & Leaf & Stem & Shoot & CW & OE & SF & & & \\
\hline Ceratopteris pteridoides & 1316.34 & 191.38 & 186.19 & & $28-69$ & $14-44$ & $6-46$ & $\begin{array}{l}27.99 \\
570.75\end{array}$ & $0.10-0.14$ & {$[16]$} \\
\hline Lantana camara L. & 293.4 & 423.06 & 392.37 & 301.78 & & & & $1.32-3.14$ & $1.04-1.41$ & [29] \\
\hline Myriophyllum aquaticum & & 122.530 & 111.828 & & $24.92-38.57$ & $0.97-12.04$ & $57.40-66.25$ & & & [12] \\
\hline Calendula calypso & 165 & & & 78 & & & & $2.7-4.14$ & $0.46-0.50$ & [17] \\
\hline Koelreuteria paniculata & 8.48 & 4.04 & 2.31 & & $45-77$ & 2-11 & $20-45$ & $0.052-0.318$ & $0.464-0.705$ & [116] \\
\hline Echinodorus Osiris Rataj & 2742.95 & & & 502.97 & $8.44-25.62$ & -22.07 & $69.49-88.39$ & $>1$ & 0.18 & [11] \\
\hline Raphanus sativus L. & $3.52-4.94$ & & & $4.66-6.86$ & $18-49$ & $15-20$ & $36-51$ & $1.64-2.36$ & $1.32-1.38$ & [13] \\
\hline Morus alba L. & 31.6 & 8.57 & 15 & & $31-77$ & $3-13$ & $16-66$ & $0.10-0.35$ & $0.12-0.27$ & [117] \\
\hline
\end{tabular}

SD: subcellular distribution; BCF: bioconcentration factor; TF: transport factor; CW: cell wall; OE: organelle; SF: soluble fraction; Refs: references.

Moreover, the distribution of $\mathrm{Cd}$ at the plant subcellular level is uneven (Table 2). In Monashree's research, the overall Cd accumulation was as follows: cell wall $(28-69 \%)>$ organelles $(14-44 \%)>$ soluble fractions $(6-46 \%)$. However, Cd distribution in the same subcellular tissue of different plant differs. The difference is that, under the treatments of $10 \mu \mathrm{M}, 20 \mu \mathrm{M}$, and $40 \mu \mathrm{M} \mathrm{Cd}$ (hydroponics), the content of Cd in the soluble fractions of the leaves is higher than that in the organelles [16]. In Wang's study [9], the subcellular distribution (the ratio of total $\mathrm{Cd}$ in different subcellular structure to the total $\mathrm{Cd}$ in the whole cell) of $\mathrm{Cd}$ in soybean roots at $23 \mu \mathrm{M}$ and $45 \mu \mathrm{M}$ levels was as follows: cell wall $(53.4-75.5 \%)>$ soluble fraction $(15.8-40.4 \%)>$ organelles $(2.0-14.7 \%)$, while the shoot soluble fraction $(39.3-74.8 \%)>$ cell wall $(16.0-52.0 \%)$. Similar to the subcellular distribution in soybean roots, the subcellular distribution of $\mathrm{Cd}$ in the $\mathrm{Cd}$ hyperaccumulator, Solanum nigrum, was cell wall $(62-66 \%)>$ soluble fraction $(26-32 \%)>$ organelle $(5-7 \%)$ [115]. This indicates that the root cell wall is the main subcellular location for plants to store $\mathrm{Cd}$, which is achieved by the retention effect of roots, followed by $\mathrm{Cd}$ transported to shoots and stored in the vacuole in the form of soluble fractions. Thlaspi caerulescens [39], a Cd hyperaccumulator, can accumulate high concentrations of $\mathrm{Cd}$ and $\mathrm{Zn}$ in the leaves. Further research found that $91 \%$ of the $\mathrm{Cd}$ in leaves was stored in protoplasts and located in vacuoles. This may be related to the fact that $\mathrm{Cd}$ is stored in vacuoles of plant cells through chelation and compartmentalisation, including heavy metal ions interacting with ligands.

The distribution and subcellular distribution of $\mathrm{Cd}$ in plants are uneven due to differences in plant species and varieties. At present, the distribution and subcellular distribution of $\mathrm{Cd}$ in plants as physiological and biochemical characteristics have been widely studied by scholars, but there is no unified understanding of whether the difference in its distribution is related to the significance of enrichment and tolerance.

\section{The Mechanisms of Plant Enrichment of Cd}

Under Cd stress, plants show a series of physiological responses to achieve detoxification and enrichment of heavy metals (Figure 2). Current studies have shown that the main response mechanisms of plants under $\mathrm{Cd}$ stress are the retention effect of roots, compartmentalisation, chelation, antioxidation, stress, and osmotic adjustment $[43,118]$. Among them, root function, compartmentalisation, and chelation in plants are the dominant factors in the process of $\mathrm{Cd}$ enrichment. Other plant response mechanisms also 
play an important role in achieving $\mathrm{Cd}$ enrichment in plants, regulating physiology, and maintaining life activities.

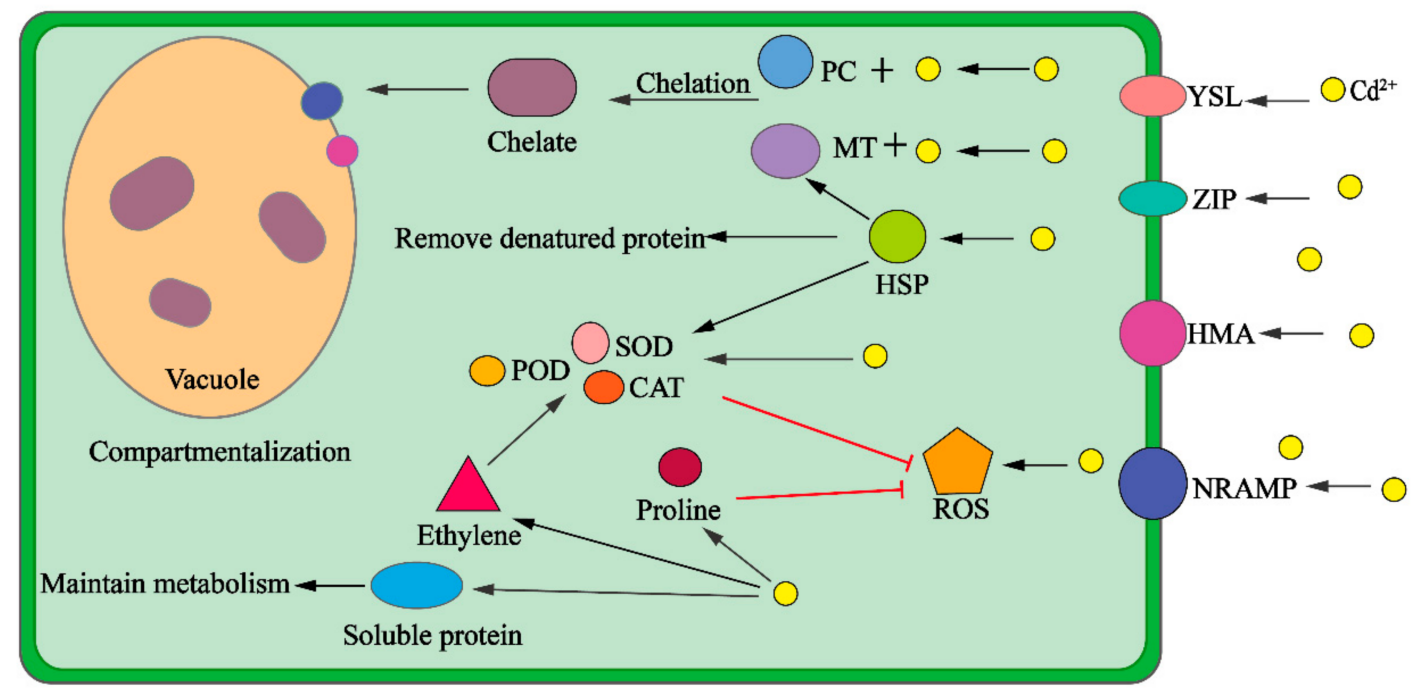

Figure 2. The mechanisms of compartmentalization, chelation, antioxidation, stress, and osmotic adjustment in plants. PC: phytochelatin; MT: metallothionein; HSP: heat shock protein; ROS: reactive oxygen species; SOD: superoxide dismutase; POD: peroxidase; CAT: catalase; YSL: yellow-stripe 1-like transporter; ZIP: zinc-regulated and iron-regulated transporter-like protein; HMA: heavy metal ATPase; NRAMP: natural resistance-associated macrophage protein.

$\mathrm{Cd}^{2+}$ enters the cell by combining with transporters such as YSL, ZIP, HMA, and NRAMP and with small molecules such as phytochelatin (PC) to form chelates, which are transported to the vacuole to achieve compartmentalisation. $\mathrm{Cd}^{2+}$ can stimulate the production of ROS, cause oxidative stress, and stimulate the plant's antioxidant defence system. Antioxidant enzymes, such as superoxide dismutase (SOD), peroxidase (POD), and catalase (CAT), eliminate reactive oxygen species (ROS) through increased activity. Heat shock protein (HSP) induced by stress can upregulate antioxidant enzyme activity, upregulate MT expression, and remove denatured proteins. Appropriate ethylene synthesis can also regulate antioxidant activity. The increase in proline content is conducive to the elimination of ROS, and an increase in soluble protein content is conducive to maintaining cell stability and cell metabolism.

\subsection{The Role of Plant Roots}

Plant roots serve as the first barrier for $\mathrm{Cd}$ entering plants. The root secretions and the cell wall of root epidermal cells play an important role in limiting $\mathrm{Cd}$ uptake and $\mathrm{Cd}$ accumulation in the roots [58]. Root exudates can form complexes or precipitates with external $\mathrm{Cd}$, thereby retaining $\mathrm{Cd}$ on the root epidermis [119]; organic acids in different types of root exudates also have different adsorption effects on $\mathrm{Cd}$ in the soil, so that $\mathrm{Cd}$ in the soil enters the plant roots in different chemical forms. Therefore, the bioavailability of $\mathrm{Cd}$ in the soil environment can be conversed by changing the root exudates [119]. Lowering the $\mathrm{pH}$ increases the solubility of $\mathrm{Cd}$ compounds in the soil and, hence, the bioavailability of $\mathrm{Cd}^{2+}$. An appropriate concentration of root exudates can promote the transfer of $\mathrm{Cd}$ from roots to leaves for accumulation in the leaves [119]. The root cell wall is mainly composed of cellulose, hemicellulose, and pectin, which are rich in hydroxyl, thiol, and carboxyl functional groups. These functional groups can bind to $\mathrm{Cd}^{2+}$ so that $\mathrm{Cd}$ can be retained in the root cell wall $[117,120]$. Cd in roots mainly accumulates in the cortical tissues of root tips and root hairs. Due to the existence of the Casparian strip in the endothelium, the transport of $\mathrm{Cd}$ to the central pillar is further prevented [121]. Wang et al. showed that $\mathrm{Cd}$ had the highest content in root cell walls, and the retention effect of the cell wall on Cd greatly reduced the damage of $\mathrm{Cd}$ to plant cells [9]. Cheng et al. [37] found that a 
large amount of $\mathrm{Cd}$ accumulated in the xylem vessel and xylem cell wall of the Northeast Dandelion root system, indicating that one of the important reasons for Taraxacum ohwianum Kitam. to tolerate Cd stress was the retention of the root cell wall to $\mathrm{Cd}$. However, the abovementioned studies have not conducted in-depth studies on how plants regulate the retention of $\mathrm{Cd}$ in the roots and the restriction of $\mathrm{Cd}$ uptake. It is necessary to reveal the mechanisms by which plant roots absorb $\mathrm{Cd}$ and of $\mathrm{Cd}$ enrichment.

\subsection{Compartmentalization and Chelation}

After heavy metal ions enter the plant, they can be chelated or even precipitated by metallothioneins (MT), phytochelatins (PC), glutathione, oxalic acid, citric acid, and other small molecules in the plant cytoplasm and vacuoles, thus reducing their toxicity [122,123]. MT is a small protein that is rich in cysteine. It is produced in response to heavy metal ions entering the plant $[124,125]$. The study found that the $\mathrm{Cd}$ tolerance and accumulation ability of yeast enhanced after inserting rice MT1e [126], which was consistent with the results of Gu et al. [127], and Chen et al. [128]. The binding of heavy metal ions to the cysteine-rich regions may be one of the mechanisms that plants use for detoxification [129]. PC is a type of sulfhydryl polypeptide containing cysteine, glutamic acid, and glycine synthesised by plants after being stressed by heavy metals [130]. It was first extracted from Rauvolfia serpentina and identified by Grill et al. [131]. It was found that it is not the same substance as MT. In the presence of $\mathrm{Cd}^{2+}, \mathrm{PC}$ synthesised combines with $\mathrm{Cd}^{2+}$ to form a complex and is then transported by transporters or transported through vesicles to inactive organelles (mainly vacuoles) for compartmentalisation [132-134].

Plants transport heavy metals that enter the plant to inactive areas such as cell walls and vacuoles, retain them, and reduce the fluidity of heavy metals by isolating them. This mechanism is called compartmentalisation $[40,135]$. Vacuoles are the main sites for the storage of heavy metal ions in hyperaccumulators. Vacuole compartmentalisation is one of the mechanisms by which plants enrich and tolerate $\mathrm{Cd}$ and is also an important criterion for screening hyperaccumulators [40]. The transport mechanism of vacuole compartmentalisation is divided into two types: transport directly through the transporter on the vacuole, and transport through the vesicle in the cytoplasm and the vacuole membrane [136]. Allan et al. [137] found that Cd easily combines with amino, carboxyl, hydroxyl, and other coordination groups in cell wall proteins and polysaccharides to realise the cell wall compartmentalisation of $\mathrm{Cd}$. When the $\mathrm{Cd}^{2+}$ accumulation in the cell wall is higher enough, $\mathrm{Cd}$ is then transported to the vacuole. Cd can combine with proteins, organic acids, sugars, and other organic substances in the vacuole to form macromolecular compounds through chelation, thereby reducing the toxicity of Cd [138,139]. Wei et al. [140] found that, after the heavy metals $\mathrm{Cd}$ and $\mathrm{Cu}$ entered the Eucalyptus cells, they were transported to the soluble fractions to reduce damage to the organelles. This proves that the compartmentalisation of soluble fractions is an important mechanism for Eucalyptus to accumulate and tolerate Cd [141,142]. Tian et al. showed that the main Cd enrichment sites in Sedum alfredii were the cortex and mesophyll tissue, and most of them were located in the vacuole [143], which is consistent with the findings of Huang et al. [117] and Zhang et al. [11].

\subsection{Antioxidant System}

Reactive oxygen species (ROS) play an important role in controlling plant growth, the abiotic stress response, system signal transmission, programmed cell death, and plant development [144]. When the content of ROS in plants increases, the accumulated ROS leads to membrane lipid peroxidation, cell membrane rupture, electrolyte leakage, and DNA loss, which affect the normal physiological and biochemical functions of cells [145]. As ROS levels increase, the antioxidant defence system in plants is activated. As an important part of the antioxidant defence system, antioxidant enzymes in plants can help eliminate ROS and reduce plant damage $[26,146]$. These enzymes include superoxide dismutase (SOD), catalase (CAT), peroxidase (POD), glutathione peroxidase (GSH-Px), and ascorbate peroxidase (APX). Cd induces ROS production by stimulating NADPH 
oxidase activity, replacing essential cations at specific binding sites, and inhibiting enzyme activity [147].

Once the plant is stressed by $\mathrm{Cd}$, the plant will adjust the activity of these antioxidant enzymes accordingly, but this change will vary depending on the plant species, the length of exposure to heavy metals, and the growth stage of the plant [148]. Upon exposure to low Cd concentrations in Ceratopteris pteridoides [16], the activities of SOD, CAT, and POD are upregulated and increase with the addition of $\mathrm{Cd}$, which is consistent with results for Vallisneria natans [27], Solanum nigrum L. [115], perennial ryegrass [149], Lantana camara L. [29], and Calendula calypso [17]; this might be caused by the increase in antioxidant enzyme synthesis under the stimulation of ROS. However, there is a critical value of $\mathrm{Cd}$ concentration (70-120 mg kg$\left.{ }^{-1}, \mathrm{DW}\right)$, beyond which the antioxidant enzyme activity no longer increases or even decreases, indicating that the ROS content in the plant exceeds the antioxidant enzyme scavenging ability. The rate of antioxidant enzyme synthesis will also be affected and cannot resist oxidative damage under high $\mathrm{Cd}$ stress $[33,34,116,150]$. Lian et al. [151] found that wheat seedlings exposed to Cd increased the activity of CAT and POD but decreased the activity of SOD, which may be caused by the decrease in Fe and Mn plasma concentrations that play a key role in the synthesis of SOD [152]. SOD enzyme activity in Narcissus tazeta var. chinesis roots showed an initial decline and then an upward trend with increasing $\mathrm{Cd}$ concentration. Low concentrations cause oxidative stress and increase with the addition of $\mathrm{Cd}$. High concentrations may lead to the accumulation of ROS, thereby inducing increased SOD production [153]. Yang et al. [154] found that, under a certain concentration of Cd stress, the enzyme activities of CAT, SOD, and POD in tolerant crops, such as winter wheat and other gramineous plants, increased with increasing $\mathrm{Cd}$ concentration, while the enzyme activities in plants with poor tolerance, such as cucumbers, decreased. This proves that the increase in antioxidant enzyme activity is directly related to the improvement of plant tolerance. Although antioxidant enzymes such as SOD, CAT, and POD can regulate their activity to eliminate ROS to protect plants within a certain concentration range, the activity of these antioxidant enzymes will still be inhibited at high Cd concentrations. These results have been confirmed in eggplant [115], and Taraxacum ohwianum Kitam. [37]. Some hyperaccumulators can still maintain high enzyme activity in the presence of high concentrations of $\mathrm{Cd}\left(\geq 100 \mathrm{mg} \mathrm{kg}^{-1}, \mathrm{DW}\right)$, such as Lantana camara L. [29], Solanum nigrum L. [115], Youngia japonica (L.) DC [33], and Pterocypsela laciniata [146]. Therefore, the activity of antioxidant enzymes is considered an important indicator of the ability of plants to tolerate $\mathrm{Cd}$ stress.

\subsection{Stress}

When plants are in an environment that subjects them to stresses such as high temperature or the presence of heavy metals, plants begin to synthesise heat shock proteins (HSPs), chitinases, and pathogen-related proteins $[155,156]$. HSP maintains normal cell metabolism by upregulating the activity of ROS scavenging enzymes (including antioxidant enzymes), reducing ROS accumulation, and removing denatured proteins. It can also bind to cytoplasmic phosphorylated proteins to regulate antioxidant enzyme activity, induce melatonin production, and upregulate MT expression, thereby improving the ability of cells to tolerate Cd [157-159], which may be related to the DNA-binding domain in the heat shock transcription factor, HsfA4a [160]. In addition to the synthesis of HSP, plants can also induce ethylene production under Cd stress. Liu et al. [161] and Schellingen et al. [162] both confirmed this, and further found that $\mathrm{Cd}$ transported from roots to shoots can increase the ethylene content of shoots. Cd stress can upregulate the expression of 1-aminocyclopropane-1-carboxylic acid (ethylene synthesis precursor) synthase to induce ethylene synthesis, and further regulate the growth inhibition of plant roots by regulating XTH33 and LSU1 mediated by the transcription factor, EIN3 [163,164]. In addition, ethylene can control the SOD content by increasing the activity of SOD isoenzymes, but excessively high ethylene levels inhibit the activities of antioxidant enzymes such as CAT and APX $[165,166]$. Therefore, it is possible to strengthen the antioxidant defence ability 
by maintaining an appropriate level of ethylene, thereby increasing the plant's ability to enrich and tolerate cadmium.

\subsection{Osmotic Adjustment}

After Cd stress, plants can also increase the cell osmotic potential by changing the content of osmotic adjustment substances, including proline, soluble protein, soluble sugar, and small molecular organic acids, thereby eliminating the toxic effect of $\mathrm{Cd}$ on plants $[167,168]$. Proline is an osmotic regulator that exists in a free state, which not only protects the integrity of proteins and prevents enzyme dehydration and inactivation but also scavenges ROS free radicals [169]. Zouari et al. [170] found that the addition of exogenous proline $(20 \mathrm{mM})$ to date palms increased antioxidant enzyme activity and reduced the oxidative damage caused by $\mathrm{Cd}$ in plants. The same result was observed in Olea europaea. L [171]. Solanum nigrum L. [115] and Parthenium hysterophorus L. [172] significantly increased the proline content under Cd stress, which proved that proline participates in osmotic regulation under Cd stress. In addition, Zhou, et al. [173] found that the soluble sugar content after $\mathrm{Cd}$ treatment was significantly higher than that of the control group, which was consistent with the results of Rady et al. [174]. By increasing the content of soluble protein and soluble sugar in plants, the intracellular osmotic potential can be increased, and the intracellular water content can be maintained, which is helpful in alleviating electrolyte leakage caused by oxidative stress and maintaining the normal physiological function of cells $[175,176]$. However, the increase in soluble protein content in soybean endosperm is accompanied by a decrease in soluble protein content and soluble sugar content in the radicle [177], which might be related to the inhibitory effect of $C d$ on the activities of hydrolytic enzymes, including $\alpha$-amylase, $\beta$-amylase, acid phosphatase, and alkaline phosphatase [178]. This suggests that complex osmotic regulatory networks exist in plants that can regulate cell osmotic potential through a series of complex responses to $\mathrm{Cd}$ stress to reduce the toxic effects of $\mathrm{Cd}$ on plants.

\section{Conclusions and Outlook}

As a widespread pollutant in the environment, $\mathrm{Cd}$ not only affects the physiological and biochemical functions of plants but can also be ingested by the human body through the biological chain to have a serious impact on health. $\mathrm{Cd}$ in the environment can interact with plant root cell walls or root exudates to be adsorbed on roots, enter plant roots through active or passive absorption, be transported by symplast pathway or apoplast pathway, and transport to shoots through the xylem. Plants use root retention to restrict $\mathrm{Cd}$ from being transported to shoots [121]. If $\mathrm{Cd}^{2+}$ enters the cell, it combines with small proteins and peptides such as MTs and PCs to attenuate the toxicity of Cd. Cd can be compartmentalised to reduce fluidity and achieve intracellular enrichment. In this process, $\mathrm{Cd}$ is combined with YSL, ZIP, HMA, NRAMP, and other transporters and is finally distributed to various tissues of the plant, mainly in the cell wall of plant roots and the vacuole of shoots. As an abiotic stress factor, $\mathrm{Cd}$ can stimulate the antioxidant defence system of plants. In response to the oxidative damage caused by $\mathrm{Cd}$, plants reduce $\mathrm{ROS}$ by regulating the activity of antioxidant enzymes and synthesising HSP. The synthesis of appropriate levels of ethylene can help improve the antioxidant defence capabilities. In addition, osmotic adjustment substances such as proline, soluble protein, and soluble sugar can also reduce the oxidative damage caused by $\mathrm{Cd}$ to plants and exert detoxification effects to further enhance the enrichment of $\mathrm{Cd}$ in plants.

The use of hyperaccumulators to reduce $\mathrm{Cd}$ pollution is a promising phytoremediation method. Many scholars have obtained important research results on the molecular mechanisms of $\mathrm{Cd}$ uptake, distribution, and transport, as well as the molecular mechanism of plant enrichment and tolerance to $\mathrm{Cd}$. However, there are still many problems that have not been resolved, such as the significance of the difference in the distribution of $\mathrm{Cd}$ in plants for plants to adapt to the environment and maintain their physiological functions; the chemical, morphological changes of $\mathrm{Cd}$ in the process of transport and the 
molecular mechanism of its binding to transporters; the regulatory mechanism of compartmentalisation and chelation; the regulatory mechanism of antioxidant enzyme activity under Cd stress; and the osmotic regulatory mechanism under Cd stress. In the process of $\mathrm{Cd}$ absorption and transport, the structure and morphology of the transporter changes, as do the interactions between different proteins. If the above problems can be solved, research on the mechanism of $\mathrm{Cd}$ enrichment in plants will take a big step forward, and phytoremediation technology can be used to treat heavy metal pollution.

Author Contributions: G.-L.Y. conceived and designed the review. G.-L.Y. and M.-M.Z. wrote the review. A.-J.T., Y.-T.L., D.F. and S.-M.L. revised the review. All authors have read and agreed to the published version of the manuscript.

Funding: This research was funded by National Natural Science Foundation of China (No. 32001203 and No. 31760749), Guizhou Science and Technology Support Plan Project (No. Qian-Ke-He-ZhiCheng [2018] 2276), and Guizhou University Research Project for Introducing Talent (No. Gui-DaRen-Ji-He-Zi [2019] 60).

Institutional Review Board Statement: Not applicable.

Informed Consent Statement: Not applicable.

Acknowledgments: We thank Lin Fu for the technical support.

Conflicts of Interest: The authors declare no conflict of interest. The funders had no role in the design of the study; in the collection, analyses, or interpretation of data; in the writing of the manuscript, or in the decision to publish the results.

\section{References}

1. Jeong, H.; Choi, J.Y.; Lee, J.; Lim, J.; Ra, K. Heavy metal pollution by road-deposited sediments and its contribution to total suspended solids in rainfall runoff from intensive industrial areas. Environ. Pollut. 2020, 265, 115028. [CrossRef] [PubMed]

2. Weissmannová, H.D.; Mihočová, S.; Chovanec, P.; Pavlovský, J. Potential Ecological Risk and Human Health Risk Assessment of Heavy Metal Pollution in Industrial Affected Soils by Coal Mining and Metallurgy in Ostrava, Czech Republic. Int. J. Environ. Res. Public Health 2019, 16, 4495. [CrossRef] [PubMed]

3. Fang, T.; Yang, K.; Lu, W.; Cui, K.; Li, J.; Liang, Y.; Hou, G.; Zhao, X.; Li, H. An overview of heavy metal pollution in Chaohu Lake, China: Enrichment, distribution, speciation, and associated risk under natural and anthropogenic changes. Environ. Sci. Pollut. Res. 2019, 26, 29585-29596. [CrossRef] [PubMed]

4. Gu, J.G.; Zhou, Q.X.; Wang, X. Reused Path of Heavy Metal Pollution in Soils and its Research Advance. J. Basic Sci. Engine 2003, 02, 143-151.

5. Zhao, F.-J.; Ma, Y.; Zhu, Y.-G.; Tang, Z.; McGrath, S.P. Soil contamination in China: Current status and mitigation strategies. Environ. Sci. Technol. 2015, 49, 750-759. [CrossRef] [PubMed]

6. Yuan, X.; Xue, N.; Han, Z. A meta-analysis of heavy metals pollution in farmland and urban soils in China over the past 20 years. J. Environ. Sci. 2021, 101, 217-226. [CrossRef]

7. Yang, Q.; Li, Z.; Lu, X.; Duan, Q.; Huang, L.; Bi, J. A review of soil heavy metal pollution from industrial and agricultural regions in China: Pollution and risk assessment. Sci. Total Environ. 2018, 642, 690-700. [CrossRef]

8. Shahid, M.; Dumat, C.; Khalid, S.; Niazi, N.K.; Antunes, P.M.C. Cadmium Bioavailability, Uptake, Toxicity and Detoxification in Soil-Plant System. Rev. Environ. Contam. Toxicol. 2016, 241, 73-137. [CrossRef]

9. Wang, P.; Deng, X.; Huang, Y.; Fang, X.; Zhang, J.; Wan, H.; Yang, C. Comparison of subcellular distribution and chemical forms of cadmium among four soybean cultivars at young seedlings. Environ. Sci. Pollut. Res. 2015, 22, 19584-19595. [CrossRef] [PubMed]

10. Pan, H.J.; Liu, J.T.; Ma, S.H.; Zhao, S.Z.; Zhong, R.; Liu, Y.B.; Zhao, J.Z. Occurrence characteristics of cadmium in atmospheric dustfall in Baotou City. J. Inner. Mong. Agric. Univ. 2010, 31, 105-109.

11. Zhang, C.; Zhang, P.; Mo, C.; Yang, W.; Li, Q.; Pan, L.; Lee, D.K. Cadmium uptake, chemical forms, subcellular distribution, and accumulation in Echinodorus osiris Rataj. Environ. Sci. Process. Impacts 2013, 15, 1459-1465. [CrossRef]

12. Li, G.; Li, Q.; Wang, L.; Zhang, D. Cadmium tolerance and detoxification in Myriophyllum aquaticum: Physiological responses, chemical forms, and subcellular distribution. Environ. Sci. Pollut. Res. Int. 2020, 27, 37733-37744. [CrossRef] [PubMed]

13. Xin, J.; Zhao, X.; Tan, Q.; Sun, X.; Hu, C. Comparison of cadmium absorption, translocation, subcellular distribution and chemical forms between two radish cultivars (Raphanus sativus L.). Ecotoxicol. Environ. Saf. 2017, 145, 258-265. [CrossRef] [PubMed]

14. Augustsson, A.; Uddh-Söderberg, T.; Filipsson, M.; Helmfrid, I.; Berglund, M.; Karlsson, H.; Hogmalm, J.; Karlsson, A.; Alriksson, S. Challenges in assessing the health risks of consuming vegetables in metal-contaminated environments. Environ. Int. 2018, 113, 269-280. [CrossRef] 
15. Telford, J.N.; Thonney, M.; Hogue, D.E.; Stouffer, J.R.; Bache, C.A.; Gutenmann, W.H.; Lisk, D.J.; Babish, J.G.; Stoewsand, G.S. Toxicologic studies in growing sheep fed silage corn cultured on municipal sludge-amended acid subsoil. J. Toxicol. Environ. Health Part A 1982, 10, 73-85. [CrossRef] [PubMed]

16. Bora, M.S.; Gogoi, N.; Sarma, K.P. Tolerance mechanism of cadmium in Ceratopteris pteridoides: Translocation and subcellular distribution. Ecotoxicol. Environ. Safe 2020, 197, 110599. [CrossRef]

17. Farooq, A.; Nadeem, M.; Abbas, G.; Shabbir, A.; Khalid, M.S.; Javeed, H.M.R.; Saeed, M.F.; Akram, A.; Younis, A.; Akhtar, G Cadmium Partitioning, Physiological and Oxidative Stress Responses in Marigold (Calendula calypso) Grown on Contaminated Soil: Implications for Phytoremediation. Bull. Environ. Contam. Toxicol. 2020, 105, 270-276. [CrossRef]

18. Jolly, Y.N.; Islam, A.; Akbar, S. Transfer of metals from soil to vegetables and possible health risk assessment. SpringerPlus 2013, 2, 1-8. [CrossRef]

19. Brams, E.; Anthony, W. Cadmium and lead through an agricultural food chain. Sci. Total Environ. 1983, 28, 295-306. [CrossRef]

20. Paithankar, J.G.; Saini, S.; Dwivedi, S.; Sharma, A.; Chowdhuri, D.K. Heavy metal associated health hazards: An interplay of oxidative stress and signal transduction. Chemosphere 2021, 262, 128350. [CrossRef]

21. Cheng, C.-H.; Ma, H.-L.; Deng, Y.-Q.; Feng, J.; Jie, Y.-K.; Guo, Z.-X. Oxidative stress, cell cycle arrest, DNA damage and apoptosis in the mud crab (Scylla paramamosain) induced by cadmium exposure. Chemosphere 2021, 263, 128277. [CrossRef] [PubMed]

22. Júnior, J.E.G.P.; Moraes, P.Z.; Rodriguez, M.D.; Simões, M.R.; Cibin, F.; Pinton, S.; Junior, F.B.; Peçanha, F.M.; Vassallo, D.V.; Miguel, M.; et al. Cadmium exposure activates NADPH oxidase, renin-angiotensin system and cyclooxygenase 2 pathways in arteries, inducing hypertension and vascular damage. Toxicol. Lett. 2020, 333, 80-89. [CrossRef] [PubMed]

23. Satarug, S.; Moore, M.R. Adverse health effects of chronic exposure to low-level cadmium in foodstuffs and cigarette smoke. Environ. Health Perspect. 2004, 112, 1099-1103. [CrossRef] [PubMed]

24. Wan, Y.; Wang, K.; Liu, Z.; Yu, Y.; Wang, Q.; Li, H. Effect of selenium on the subcellular distribution of cadmium and oxidative stress induced by cadmium in rice (Oryza sativa L.). Environ. Sci. Pollut. Res. 2019, 26, 16220-16228. [CrossRef] [PubMed]

25. Zhang, R.R.; Zhang, P.; Du, S.T. Oxidative stress-related signals and their regulation under Cd stress: A review. J. Appl. Ecol. 2016, 27, 981-992.

26. Singh, S.; Eapen, S.; D'Souza, S. Cadmium accumulation and its influence on lipid peroxidation and antioxidative system in an aquatic plant, Bacopa monnieri L. Chemosphere 2006, 62, 233-246. [CrossRef]

27. Huang, S.; Song, Q.; Li, Q.; Zhang, H.; Luo, X.; Zheng, Z. Damage of heavy metals to Vallisneria natans (V. natans) and characterization of microbial community in biofilm. Aquat. Toxicol. 2020, 225, 105515. [CrossRef]

28. Andresen, E.; Kappel, S.; Stärk, H.; Riegger, U.; Borovec, J.; Mattusch, J.; Heinz, A.; Schmelzer, C.; Matoušková, Š.; Dickinson, B.; et al. Cadmium toxicity investigated at the physiological and biophysical levels under environmentally relevant conditions using the aquatic model plant Ceratophyllum demersum. New Phytol. 2016, 210, 1244-1258. [CrossRef]

29. Liu, S.; Ali, S.; Yang, R.; Tao, J.; Ren, B. A newly discovered Cd-hyperaccumulator Lantana camara L. J. Hazard. Mater. 2019, 371, 233-242. [CrossRef]

30. Hu, Y.; Tian, S.; Foyer, C.H.; Hou, D.; Wang, H.; Zhou, W.; Liu, T.; Ge, J.; Lu, L.; Lin, X. Efficient phloem transport significantly remobilizes cadmium from old to young organs in a hyperaccumulator Sedum alfredii. J. Hazard. Mater. 2019, 365, 421-429. [CrossRef] [PubMed]

31. Küpper, H.; Leitenmaier, B. Cadmium-accumulating plants. Met. Ions Life Sci. 2012, 11, 373-393. [CrossRef]

32. Jaffre, T.; Brooks, R.R.; Lee, J.; Reeves, R.D. Sebertia acuminata: A Hyperaccumulator of Nickel from New Caledonia. Science 1976, 193, 579-580. [CrossRef]

33. Yu, B.; Peng, Y.; Xu, J.; Qin, D.; Gao, T.; Zhu, H.; Zuo, S.; Song, H.; Dong, J. Phytoremediation potential of Youngia japonica (L.) DC: A newly discovered cadmium hyperaccumulator. Environ. Sci. Pollut. Res. 2021, 28, 6044-6057. [CrossRef]

34. Zhong, L.; Lin, L.; Liao, M.; Wang, J.; Tang, Y.; Sun, G.; Liang, D.; Xia, H.; Wang, X.; Zhang, H.; et al. Phytoremediation potential of Pterocypsela laciniata as a cadmium hyperaccumulator. Environ. Sci. Pollut. Res. 2019, 26, 13311-13319. [CrossRef]

35. Liu, H.; Zhao, H.; Wu, L.; Liu, A.; Zhao, F.; Xu, W. Heavy metal ATPase 3 (HMA3) confers cadmium hypertolerance on the cadmium/zinc hyperaccumulator Sedum plumbizincicola. New Phytol. 2017, 215, 687-698. [CrossRef]

36. Lan, X.-Y.; Yan, Y.-Y.; Yang, B.; Li, X.-Y.; Xu, F.-L. Subcellular distribution of cadmium in a novel potential aquatic hyperaccumulator-Microsorum pteropus. Environ. Pollut. 2019, 248, 1020-1027. [CrossRef] [PubMed]

37. Cheng, H.T. Research on Cd Absorption, Accumulation and Tolerance of Taraxacum ohwianum Kitam. Ph.D. Thesis, Shenyang Agricultural University, Shenyang, China, 2019.

38. Xu, X.; Zhang, S.; Cheng, Z.; Li, T.; Jia, Y.; Wang, G.; Yang, Z.; Xian, J.; Yang, Y.; Zhou, W. Transcriptome analysis revealed cadmium accumulation mechanisms in hyperaccumulator Siegesbeckia orientalis L. Environ. Sci. Pollut. Res. 2020, 27, 18853-18865. [CrossRef] [PubMed]

39. Ma, J.F.; Ueno, D.; Zhao, F.-J.; McGrath, S.P. Subcellular localisation of Cd and Zn in the leaves of a Cd-hyperaccumulating ecotype of Thlaspi caerulescens. Planta 2005, 220, 731-736. [CrossRef] [PubMed]

40. Küpper, H.; Lombi, E.; Zhao, F.-J.; McGrath, S.P. Cellular compartmentation of cadmium and zinc in relation to other elements in the hyperaccumulator Arabidopsis halleri. Planta 2000, 212, 75-84. [CrossRef] [PubMed]

41. Kowalkowski, T.; Krakowska, A.; Złoch, M.; Hrynkiewicz, K.; Buszewski, B. Cadmium-affected synthesis of exopolysaccharides by rhizosphere bacteria. J. Appl. Microbiol. 2019, 127, 713-723. [CrossRef] 
42. Liu, S.; Yang, B.; Liang, Y.; Xiao, Y.; Fang, J. Prospect of phytoremediation combined with other approaches for remediation of heavy metal-polluted soils. Environ. Sci. Pollut. Res. 2020, 27, 16069-16085. [CrossRef]

43. Ismael, M.A.; Elyamine, A.M.; Moussa, M.G.; Cai, M.; Zhao, X.; Hu, C. Cadmium in plants: Uptake, toxicity, and its interactions with selenium fertilizers. Metallomics 2019, 11, 255-277. [CrossRef] [PubMed]

44. Riaz, M.; Kamran, M.; Rizwan, M.; Ali, S.; Parveen, A.; Malik, Z.; Wang, X. Cadmium uptake and translocation: Selenium and silicon roles in Cd detoxification for the production of low Cd crops: A critical review. Chemosphere 2021, 273, 129690. [CrossRef] [PubMed]

45. Li, J.T.; Gurajala, H.K.; Wu, L.H.; Ent, A.; Qiu, R.L.; Baker, A.J.M.; Tang, Y.T.; Yang, X.E.; Shu, W.S. Hyperaccumulator Plants from China: A Synthesis of the Current State of Knowledge. Environ. Sci. Technol. 2018, 52, 11980-11994. [CrossRef] [PubMed]

46. Cutler, J.M.; Rains, D.W. Characterization of cadmium uptake by plant tissue. Plant Physiol. 1974, 54, 67-71. [CrossRef] [PubMed]

47. Harrison, R.M.; Chirgawi, M. The assessment of air and soil as contributors of some trace metals to vegetable plants. II. Translocation of atmospheric and laboratory-generated cadmium aerosols to and within vegetable plants. Sci. Total Environ. 1989, 83, 35-45. [CrossRef]

48. Hauser, L.; Tandy, S.; Schulin, R.; Nowack, B. Column extraction of heavy metals from soils using the biodegradable chelating agent EDDS. Environ. Sci. Technol. 2005, 39, 6819-6824. [CrossRef] [PubMed]

49. Meychik, N.R.; Nikolaeva, Y.I.; Yermakov, I.P. Ion-exchange properties of cell walls of Spinacia oleracea L. roots under different environmental salt conditions. Biochemistry 2006, 71, 781-789. [CrossRef]

50. Palusińska, M.; Barabasz, A.; Kozak, K.; Papierniak, A.; Maślińska, K.; Antosiewicz, D.M. Zn/Cd status-dependent accumulation of $\mathrm{Zn}$ and $\mathrm{Cd}$ in root parts in tobacco is accompanied by specific expression of ZIP genes. BMC Plant Boil. 2020, 20, 37. [CrossRef]

51. Cataldo, D.A.; Garland, T.R.; Wildung, R.E. Cadmium uptake kinetics in intact soybean plants. Plant Physiol. 1983, 73, 844-848. [CrossRef]

52. Peng, K.J.; Luo, C.L.; Chen, Y.H.; Wang, G.P.; Li, X.D.; Shen, Z.G. Cadmium and other metal uptake by Lobelia chinensis and Solanum nigrum from contaminated soils. Bull. Environ. Contam. Toxicol. 2009, 83, 260-264. [CrossRef]

53. Hart, J.J.; Welch, R.M.; Norvell, W.A.; Kochian, L.V. Transport interactions between cadmium and zinc in roots of bread and durum wheat seedlings. Physiol. Plant 2002, 116, 73-78. [CrossRef]

54. De Temmerman, L.; Ruttens, A.; Waegeneers, N. Impact of atmospheric deposition of As, Cd and Pb on their concentration in carrot and celeriac. Environ. Pollut. 2012, 166, 187-195. [CrossRef]

55. Fernández, E.A.; Rossini, O.S. The composition and relationships between trace element levels in inhalable atmospheric particles (PM10) and in leaves of Nerium oleander L. and Lantana camara L/. Chemosphere 2006, 62, 1665-1672. [CrossRef] [PubMed]

56. Anda, A.; Illés, B.; Soós, G. Effect of cadmium pollution of atmospheric origin on field-grown maize in two consecutive years with diverse weather conditions. Acta Biol. Hung. 2013, 64, 476-489. [CrossRef]

57. Lu, H.; Zhang, Y.L.; Wu, Y.B. Research progress on foliar absorption mechanism of pollutants. Environ. Chem. 2020, 12, $3371-3383$.

58. Huang, X.; Duan, S.; Wu, Q.; Yu, M.; Shabala, S. Reducing Cadmium Accumulation in Plants: Structure-Function Relations and Tissue-Specific Operation of Transporters in the Spotlight. Plants 2020, 9, 223. [CrossRef] [PubMed]

59. Da Cunha, K.P.V.; Nascimento, C.W.A.D.; Pimentel, R.M.D.M.; Ferreira, C.P. Cellular localization of cadmium and structural changes in maize plants grown on a cadmium contaminated soil with and without liming. J. Hazard. Mater. 2008, 160, 228-234. [CrossRef]

60. Curie, C.; Cassin, G.; Couch, D.; Divol, F.; Higuchi, K.; Le Jean, M.; Misson, J.; Schikora, A.; Czernic, P.; Mari, S. Metal movement within the plant: Contribution of nicotianamine and yellow stripe 1-like transporters. Ann. Bot. 2008, 103, 1-11. [CrossRef]

61. Curie, C.; Panaviene, Z.; Loulergue, C.; Dellaporta, S.L.; Briat, J.-F.; Walker, E.L. Maize yellow stripe1 encodes a membrane protein directly involved in Fe (III) uptake. Nat. Cell Biol. 2001, 409, 346-349. [CrossRef]

62. Guerinot, M.L. The ZIP family of metal transporters. Biochim. Biophys. Acta Biomembr. 2000, 1465, 190-198. [CrossRef]

63. Grotz, N.; Fox, T.; Connolly, E.; Park, W.; Guerinot, M.L.; Eide, D. Identification of a family of zinc transporter genes from Arabidopsis that respond to zinc deficiency. Proc. Natl. Acad. Sci. USA 1998, 95, 7220-7224. [CrossRef]

64. Takahashi, R.; Bashir, K.; Ishimaru, Y.; Nishizawa, N.K.; Nakanishi, H. The role of heavy-metal ATPases, HMAs, in zinc and cadmium transport in rice. Plant Signal. Behav. 2012, 7, 1605-1607. [CrossRef]

65. Williams, L.E.; Mills, R.F. P (1B)-ATPases-An ancient family of transition metal pumps with diverse functions in plants. Trends Plant Sci. 2005, 10, 491-502. [CrossRef]

66. Milner, M.J.; Mitani, U.N.; Yamaji, N.; Yokosho, K.; Craft, E.; Fei, Z.; Ebbs, S.; Clemencia, Z.M.; Ma, J.F.; Kochian, L.V. Root and shoot transcriptome analysis of two ecotypes of Noccaea caerulescens uncovers the role of NcNramp1 in Cd hyperaccumulation. Plant J. 2014, 78, 398-410. [CrossRef]

67. Sasaki, A.; Yamaji, N.; Yokosho, K.; Ma, J.F. Nramp5 is a major transporter responsible for manganese and cadmium uptake in rice. Plant Cell 2012, 24, 2155-2167. [CrossRef]

68. Zhao, F.-J.; Huang, X. Cadmium Phytoremediation: Call Rice CAL1. Mol. Plant 2018, 11, 640-642. [CrossRef] [PubMed]

69. Luo, J.-S.; Huang, J.; Zeng, D.-L.; Peng, J.-S.; Zhang, G.-B.; Ma, H.-L.; Guan, Y.; Yi, H.-Y.; Fu, Y.-L.; Han, B.; et al. A defensin-like protein drives cadmium efflux and allocation in rice. Nat. Commun. 2018, 9, 1-9. [CrossRef] [PubMed]

70. Zhang, X.D.; Zhao, K.X.; Yang, Z.M. Identification of genomic ATP binding cassette (ABC) transporter genes and Cd-responsive ABCs in Brassica napus. Gene 2018, 664, 139-151. [CrossRef] [PubMed] 
71. Schaaf, G.; Ludewig, U.; Erenoglu, B.E.; Mori, S.; Kitahara, T.; von Wirén, N. ZmYS1 functions as a proton-coupled symporter for phytosiderophore- and nicotianamine-chelated metals. J. Biol. Chem. 2004, 279, 9091-9096. [CrossRef]

72. Murata, Y.; Ma, J.F.; Yamaji, N.; Ueno, D.; Nomoto, K.; Iwashita, T. A specific transporter for iron (III)-phytosiderophore in barley roots. Plant J. 2006, 46, 563-572. [CrossRef]

73. von Wirén, N.; Mori, S.; Marschner, H.; Romheld, V. Iron Inefficiency in Maize Mutant ys1 (Zea mays L. cv Yellow-Stripe) Is Caused by a Defect in Uptake of Iron Phytosiderophores. Plant Physiol. 1994, 106, 71-77. [CrossRef]

74. Das, S.; Sen, M.; Saha, C.; Chakraborty, D.; Das, A.; Banerjee, M.; Seal, A. Isolation and expression analysis of partial sequences of heavy metal transporters from Brassica juncea by coupling high throughput cloning with a molecular fingerprinting technique. Planta 2011, 234, 139-156. [CrossRef]

75. Wang, J.; Li, Y.; Zhang, Y.-X.; Chai, T.-Y. Molecular cloning and characterization of a Brassica juncea yellow stripe-like gene, BjYSL7, whose overexpression increases heavy metal tolerance of tobacco. Plant Cell Rep. 2013, 32, 651-662. [CrossRef]

76. Feng, S.; Tan, J.; Zhang, Y.; Liang, S.; Xiang, S.; Wang, H.; Chai, T. Isolation and characterization of a novel cadmium-regulated Yellow Stripe-Like transporter (SnYSL3) in Solanum nigrum. Plant Cell Rep. 2016, 36, 281-296. [CrossRef] [PubMed]

77. Palmer, C.M.; Guerinot, M.L. Facing the challenges of $\mathrm{Cu}, \mathrm{Fe}$ and Zn homeostasis in plants. Nat. Chem. Biol. 2009, 5, 333-340. [CrossRef]

78. Eng, B.; Guerinot, M.; Eide, D.; Saier, M. Sequence analyses and phylogenetic characterization of the ZIP family of metal ion transport proteins. J. Membr. Biol. 1998, 166, 1-7. [CrossRef] [PubMed]

79. Nishida, S.; Mizuno, T.; Obata, H. Involvement of histidine-rich domain of ZIP family transporter TjZNT1 in metal ion specificity. Plant Physiol. Biochem. 2008, 46, 601-606. [CrossRef] [PubMed]

80. Zhang, X.; Li, X.; Tang, L.; Peng, Y.; Qian, M.; Guo, Y.; Rui, H.; Zhang, F.; Hu, Z.; Chen, Y.; et al. The root iron transporter 1 governs cadmium uptake in Vicia sativa roots. J. Hazard. Mater. 2020, 398, 122873. [CrossRef]

81. Wu, X.; Chen, J.; Yue, X.; Wei, X.; Zou, J.; Chen, Y.; Su, N.; Cui, J. The zinc-regulated protein (ZIP) family genes and glutathione s-transferase (GST) family genes play roles in Cd resistance and accumulation of pak choi (Brassica campestris ssp. chinensis). Ecotoxicol. Environ. Saf. 2019, 183, 109571. [CrossRef]

82. Williams, L.E.; Pittman, J.K.; Hall, J. Emerging mechanisms for heavy metal transport in plants. Biochim. Biophys. Acta Biomembr 2000, 1465, 104-126. [CrossRef]

83. Argüello, J.M. Identification of ion-selectivity determinants in heavy-metal transport P1B-type ATPases. J. Membr. Biol. 2003, 195, 93-108. [CrossRef] [PubMed]

84. Wang, X.; Zhi, J.; Liu, X.; Zhang, H.; Liu, H.; Xu, J. Transgenic tobacco plants expressing a P1B-ATPase gene from Populus tomentosa Carr. (PtoHMA5) demonstrate improved cadmium transport. Int. J. Biol. Macromol. 2018, 113, 655-661. [CrossRef] [PubMed]

85. Wang, J.; Liang, S.; Xiang, W.; Dai, H.; Duan, Y.; Kang, F.; Chai, T. A repeat region from the Brassica juncea HMA4 gene BjHMA4R is specifically involved in $\mathrm{Cd}(2+)$ binding in the cytosol under low heavy metal concentrations. BMC Plant Biol. 2019, 19, 89. [CrossRef]

86. Kumagai, S.; Suzuki, T.; Tezuka, K.; Satoh-Nagasawa, N.; Takahashi, H.; Sakurai, K.; Watanabe, A.; Fujimura, T.; Akagi, H. Functional analysis of the C-terminal region of the vacuolar cadmium-transporting rice OsHMA3. FEBS Lett. 2014, 588, 789-794. [CrossRef] [PubMed]

87. Wong, C.K.E.; Cobbett, C.S. HMA P-type ATPases are the major mechanism for root-to-shoot Cd translocation in Arabidopsis thaliana. New Phytol. 2009, 181, 71-78. [CrossRef]

88. Cun, P.; Sarrobert, C.; Richaud, P.; Chevalier, A.; Soreau, P.; Auroy, P.; Gravot, A.; Baltz, A.; Leonhardt, N.; Vavasseur, A. Modulation of $\mathrm{Zn} / \mathrm{Cd} \mathrm{P}$ (1B2)-ATPase activities in Arabidopsis impacts differently on $\mathrm{Zn}$ and Cd contents in shoots and seed. Metallomics 2014, 6, 2109-2116. [CrossRef] [PubMed]

89. Migocka, M.; Papierniak, A.; Maciaszczyk-Dziubinska, E.; Posyniak, E.; Kosieradzka, A. Molecular and biochemical properties of two P1B2-ATPases, CsHMA3 and CsHMA4, from cucumbe. Plant Cell Environ. 2014, 38, 1127-1141. [CrossRef]

90. Fleming, M.; Trenor, C.C.; Su, M.A.; Foernzler, D.; Beier, D.R.; Dietrich, W.F.; Andrews, N. Microcytic anaemia mice have a mutation in Nramp2, a candidate iron transporter gene. Nat. Genet. 1997, 16, 383-386. [CrossRef]

91. Chen, S.; Han, X.; Fang, J.; Lu, Z.; Qiu, W.; Liu, M.; Sang, J.; Jiang, J.; Zhuo, R. Sedum alfredii SaNramp6 Metal Transporter Contributes to Cadmium Accumulation in Transgenic Arabidopsis thaliana. Sci. Rep. 2017, 7, 13318. [CrossRef]

92. Wang, C.; Chen, X.; Yao, Q.; Long, D.; Fan, X.; Kang, H.; Zeng, J.; Sha, L.; Zhang, H.; Zhou, Y.; et al. Overexpression of TtNRAMP6 enhances the accumulation of $\mathrm{Cd}$ in Arabidopsis. Gene 2019, 696, 225-232. [CrossRef]

93. Wei, W.; Chai, T.; Zhang, Y.; Han, L.; Xu, J.; Guan, Z. The Thlaspi caerulescens NRAMP homologue TcNRAMP3 is capable of divalent cation transport. Mol. Biotechnol. 2009, 41, 15-21. [CrossRef] [PubMed]

94. Wu, D.; Yamaji, N.; Yamane, M.; Kashino-Fujii, M.; Sato, K.; Ma, J.F. The HvNramp5 Transporter Mediates Uptake of Cadmium and Manganese, But Not Iron. Plant Physiol. 2016, 172, 1899-1910. [CrossRef] [PubMed]

95. Tiwari, M.; Sharma, D.; Dwivedi, S.; Singh, M.; Tripathi, R.D.; Trivedi, P.K. Expression in Arabidopsis and cellular localization reveal involvement of rice NRAMP, OsNRAMP1, in arsenic transport and tolerance. Plant Cell Environ. 2014, 37, 140-152. [CrossRef] [PubMed]

96. Spielmann, J.; Ahmadi, H.; Scheepers, M.; Weber, M.; Nitsche, S.; Carnol, M.; Bosman, B.; Kroymann, J.; Motte, P.; Clemens, S.; et al. The two copies of the zinc and cadmium ZIP6 transporter of Arabidopsis halleri have distinct effects on cadmium tolerance. Plant Cell Environ. 2020, 43, 2143-2157. [CrossRef] [PubMed] 
97. Safe, S.; Naira, V.; Karki, K. Metformin-induced anticancer activities: Recent insights. Biol. Chem. 2018, 399, 321-335. [CrossRef]

98. Sasaki, A.; Yamaji, N.; Ma, J.F. Overexpression of OsHMA3 enhances Cd tolerance and expression of Zn transporter genes in rice. J. Exp. Bot. 2014, 65, 6013-6021. [CrossRef]

99. Liu, X.S.; Feng, S.J.; Zhang, B.Q.; Wang, M.Q.; Cao, H.W.; Rono, J.K.; Chen, X.; Yang, Z.M. OsZIP1 functions as a metal efflux transporter limiting excess zinc, copper and cadmium accumulation in rice. BMC Plant Biol. 2019, 19, 1-16. [CrossRef]

100. Tian, S.; Liang, S.; Qiao, K.; Wang, F.; Zhang, Y.; Chai, T. Co-expression of multiple heavy metal transporters changes the translocation, accumulation, and potential oxidative stress of $\mathrm{Cd}$ and $\mathrm{Zn}$ in rice (Oryza sativa). J. Hazard. Mater. 2019, 380, 120853. [CrossRef]

101. Küpper, H.; Kochian, L.V. Transcriptional regulation of metal transport genes and mineral nutrition during acclimatization to cadmium and zinc in the Cd/Zn hyperaccumulator, Thlaspi caerulescens (Ganges population). New Phytol. 2010, 185, 114-129. [CrossRef]

102. Zhao, H.; Wang, L.; Zhao, F.-J.; Wu, L.; Liu, A.; Xu, W. SpHMA1 is a chloroplast cadmium exporter protecting photochemical reactions in the Cd hyperaccumulator Sedum plumbizincicola. Plant Cell Environ. 2018, 42, 1112-1124. [CrossRef]

103. Yu, R.; Li, D.; Du, X.; Xia, S.; Liu, C.; Shi, G. Comparative transcriptome analysis reveals key cadmium transport-related genes in roots of two pak choi (Brassica rapa L. ssp. chinensis) cultivars. BMC Genom. 2017, 18, 587. [CrossRef]

104. Wu, S.; Shi, K.; Hu, C.; Guo, J.; Tan, Q.; Sun, X. Non-invasive microelectrode cadmium flux measurements reveal the decrease of cadmium uptake by zinc supply in pakchoi root (Brassica chinensis L.). Ecotoxicol. Environ. Saf. 2019, 168, 363-368. [CrossRef]

105. Wu, X.; Zhu, Z.B.; Chen, J.H.; Huang, Y.F.; Liu, Z.L.; Zou, J.W.; Chen, Y.H.; Na Su, N.; Cui, J. Transcriptome analysis revealed pivotal transporters involved in the reduction of cadmium accumulation in pak choi (Brassica chinensis L.) by exogenous hydrogen-rich water. Chemosphere 2019, 216, 684-697. [CrossRef] [PubMed]

106. Banakar, R.; Alvarez, F.Á.; Abadía, J.; Capell, T.; Christou, P. The expression of heterologous Fe (III) phytosiderophore transporter HvYS1 in rice increases Fe uptake, translocation and seed loading and excludes heavy metals by selective Fe transport. Plant Biotechnol. J. 2017, 15, 423-432. [CrossRef] [PubMed]

107. Zhang, F.; Xiao, X.; Wu, X. Physiological and molecular mechanism of cadmium (Cd) tolerance at initial growth stage in rapeseed (Brassica napus L.). Ecotoxicol. Environ. Saf. 2020, 197, 110613. [CrossRef]

108. Peng, F.; Wang, C.; Zhu, J.; Zeng, J.; Kang, H.; Fan, X.; Sha, L.; Zhang, H.; Zhou, Y.; Wang, Y. Expression of TpNRAMP5, a metal transporter from Polish wheat (Triticum polonicum L.), enhances the accumulation of Cd, Co and Mn in transgenic Arabidopsis plants. Planta 2018, 247, 1395-1406. [CrossRef] [PubMed]

109. Tang, Z.; Cai, H.; Li, J.; Lv, Y.; Zhang, W.; Zhao, F.-J. Allelic Variation of NtNramp5 Associated with Cultivar Variation in Cadmium Accumulation in Tobacco. Plant Cell Physiol. 2017, 58, 1583-1593. [CrossRef]

110. Chen, Y.C.; Zhao, Z.J.; Sun, P.S. Distribution and control of heavy metals by addtives in soil-vegetable system in Chongqing. J. Agro Environ. Sci. 2003, 01, 44-47.

111. Lan, X.-Y.; He, Q.-S.; Yang, B.; Yan, Y.-Y.; Li, X.-Y.; Xu, F.-L. Influence of Cd exposure on H (+) and Cd (2+) fluxes in the leaf, stem and root of a novel aquatic hyperaccumulator-Microsorum pteropus. Chemosphere 2020, 249, 126552. [CrossRef]

112. Lan, H.X. Effect of $\mathrm{Pb}, \mathrm{Cd}$ and Their Compound Pollution on the Physilogical and Ecological Characteristics of the Tea. Master's Thesis, Sichuan Agricultural University, Ya'an, Sichuan Province, China, 2008.

113. Yu, Z.Y. Study on the Difference of Different Types of Soybean from Cadmium Stress. Master's Thesis, Shenyang Agricultural University, Shenyang, China, 2018.

114. He, Y. Studies on the Accumulation Characters and Influence Mechanism of Cadmium in Tobacco. Ph.D. Thesis, Chinese Academy of Agricultural Sciences, Beijing, China, 2014.

115. Guo, Z. Study on Mechanisms of Physiological Response of Hyperaccumulator Plant Solanum nigrum L. to Cadmium Stress. Ph.D. Thesis, Shanghai Jiao Tong University, Shanghai, China, 2009.

116. Yang, L.P.; Zhu, J.; Wang, P.; Zeng, J.; Tan, R.; Yang, Y.Z.; Liu, Z.M. Effect of Cd on growth, physiological response, Cd subcellular distribution and chemical forms of Koelreuteria paniculata. Ecotoxicol. Environ. Safe 2018, 160, 10-18. [CrossRef] [PubMed]

117. Huang, R.-Z.; Jiang, Y.-B.; Jia, C.-H.; Jiang, S.-M.; Yan, X.-P. Subcellular distribution and chemical forms of cadmium in Morus alba L. Int. J. Phytoremediation 2018, 20, 448-453. [CrossRef] [PubMed]

118. Zhu, T.; Li, L.; Duan, Q.; Liu, X.; Chen, M. Progress in our understanding of plant responses to the stress of heavy metal cadmium. Plant Signal. Behav. 2021, 16, 1836884. [CrossRef] [PubMed]

119. Chen, C.; Li, Z.; Li, S.; Deng, N.; Mei, P. Effects of root exudates on the activation and remediation of cadmium ion in contaminated soils. Environ. SCI Pollut. Res. Int. 2020, 27, 2926-2934. [CrossRef] [PubMed]

120. Caffall, K.H.; Mohnen, D. The structure, function, and biosynthesis of plant cell wall pectic polysaccharide. Carbohydr. Res. 2009, 344, 1879-1900. [CrossRef] [PubMed]

121. Brewin, L.E.; Mehra, A.; Lynch, P.T.; Farago, M.E. Mechanisms of copper tolerance by Armeria maritima in Dolfrwyong Bog, north Wales-initial studies. Environ. Geochem. Health 2003, 25, 147-156. [CrossRef]

122. Guo, J.; Xu, W.; Ma, M. The assembly of metals chelation by thiols and vacuolar compartmentalization conferred increased tolerance to and accumulation of cadmium and arsenic in transgenic Arabidopsis thaliana. J. Hazard. Mater. 2012, 199-200, 309-313. [CrossRef]

123. Anjum, N.A.; Hasanuzzaman, M.; Hossain, M.A.; Thangavel, P.; Roychoudhury, A.; Gill, S.S.; Rodrigo, M.A.M.; Adam, V.; Fujita, M.; Kizek, R.; et al. Jacks of metal/metalloid chelation trade in plants-An overview. Front. Plant Sci. 2015, 6, 192. [CrossRef] 
124. Morris, C.A.; Nicolaus, B.; Sampson, V.; Harwood, J.L.; Kille, P. Identification and characterization of a recombinant metallothionein protein from a marine alga, Fucus vesiculosus. Biochem. J. 1999, 338, 553-560. [CrossRef]

125. Zhang, H.; Lv, S.; Xu, H.; Hou, D.; Li, Y.; Wang, F. $\mathrm{H}_{2} \mathrm{O}_{2}$ Is Involved in the Metallothionein-Mediated Rice Tolerance to Copper and Cadmium Toxicity. Int. J. Mol. Sci. 2017, 18, 10. [CrossRef]

126. Rono, J.K.; Wang, L.; Wu, X.C.; Cao, H.W.; Zhao, Y.N.; Khan, I.U.; Yang, Z.M. Identification of a new function of metallothioneinlike gene OsMT1e for cadmium detoxification and potential phytoremediation. Chemosphere 2021, 265, 129136. [CrossRef]

127. Gu, C.-S.; Liu, L.-Q.; Zhao, Y.-H.; Deng, Y.-M.; Zhu, X.-D.; Huang, S.-Z. Overexpression of Iris lactea var. chinensis metallothionein 11MT2a enhances cadmium tolerance in Arabidopsis thaliana. Ecotoxicol. Environ. Saf. 2014, 105, 22-28. [CrossRef] [PubMed]

128. Chen, Y.; Zhi, J.; Li, X.; Zhang, H.; Liu, H.; Xu, J. Diversity in cadmium accumulation and resistance associated with various metallothionein genes (type III) in Phytolacca americana L. Int. J. Biol. Macromol. 2018, 108, 704-709. [CrossRef] [PubMed]

129. Singh, G.; Tripathi, S.; Shanker, K.; Sharma, A. Cadmium-induced conformational changes in type 2 metallothionein of medicinal plant Coptis japonica: Insights from molecular dynamics studies of apo, partially and fully metalated forms. J. Biomol. Struct. Dyn. 2018, 37, 1520-1533. [CrossRef] [PubMed]

130. Vatamaniuk, O.K.; Mari, S.; Lu, Y.-P.; Rea, P.A. AtPCS1, a phytochelatin synthase from Arabidopsis: Isolation and in vitro reconstitution. Proc. Natl. Acad. Sci. USA 1999, 96, 7110-7115. [CrossRef] [PubMed]

131. Grill, E.; Winnacker, E.-L.; Zenk, M.H. Phytochelatins: The principal heavy-metal complexing peptides of higher plants. Science 1985, 230, 674-676. [CrossRef]

132. Grill, E.; Löffler, S.; Winnacker, E.L.; Zenk, M.H. Phytochelatins, the heavy-metal-binding peptides of plants, are synthesized from glutathione by a specific gamma-glutamylcysteine dipeptidyl transpeptidase (phytochelatin synthase). Proc. Natl. Acad. Sci. USA 1989, 86, 6838-6842. [CrossRef]

133. Hirschi, K.D.; Korenkov, V.D.; Wilganowski, N.L.; Wagner, G.J. Expression of arabidopsis CAX2 in tobacco. Altered metal accumulation and increased manganese tolerance. Plant Physiol. 2000, 124, 125-134. [CrossRef]

134. Tong, Y.-P.; Kneer, R.; Zhu, Y.-G. Vacuolar compartmentalization: A second-generation approach to engineering plants for phytoremediation. Trend. Plant Sci. 2004, 9, 7-9. [CrossRef]

135. Küpper, H.; Mijovilovich, A.; Meyer-Klaucke, W.; Kroneck, P.M. Tissue- and age-dependent differences in the complexation of cadmium and zinc in the cadmium/zinc hyperaccumulator Thlaspi caerulescens (Ganges ecotype) revealed by $\mathrm{x}$-ray absorption spectroscopy. Plant Physiol. 2004, 134, 748-757. [CrossRef]

136. Sharma, S.S.; Dietz, K.J.; Mimura, T. Vacuolar compartmentalization as indispensable component of heavy metal detoxification in plants. Plant Cell Environ. 2016, 39, 1112-1126. [CrossRef]

137. Allan, D.L.; Jarrell, W.M. Proton and copper adsorption to maize and soybean root cell walls. Plant Physiol. 1989, 89, 823-832. [CrossRef]

138. Ueno, D.; Yamaji, N.; Kono, I.; Huang, C.F.; Ando, T.; Yano, M.; Ma, J.F. Gene limiting cadmium accumulation in rice. Proc. Natl. Acad. Sci. USA 2010, 107, 16500-16505. [CrossRef]

139. Weng, B.; Xie, X.; Weiss, D.J.; Liu, J.; Lu, H.; Yan, C. Kandelia obovata (S., L.) Yong tolerance mechanisms to Cadmium: Subcellular distribution, chemical forms and thiol pools. Mar. Pollut. Bull. 2012, 64, 2453-2460. [CrossRef]

140. Wei, Y.Y.; Meng, M.; Huang, X.F. Tolerance Mechanisms of Cu and Cd by Eucalyptus in Mine Contaminated Soil. Genom. Appl. Biol. 2016, 35, 227-234.

141. Guan, M.Y.; Zhang, H.H.; Pan, W.; Jin, C.W.; Lin, X.Y. Sulfide alleviates cadmium toxicity in Arabidopsis plants by altering the chemical form and the subcellular distribution of cadmium. Sci. Total Environ. 2018, 627, 663-670. [CrossRef]

142. Zhou, L.; Zhao, Y.; Wang, S. Cadmium transfer and detoxification mechanisms in a soil-mulberry-silkworm system: Phytoremediation potential. Environ. Sci. Pollut. Res. Int. 2015, 22, 18031-18039. [CrossRef] [PubMed]

143. Tian, S.; Lu, L.; Labavitch, J.; Yang, X.; He, Z.; Hu, H.; Sarangi, R.; Newville, M.; Commisso, J.; Brown, P. Cellular sequestration of cadmium in the hyperaccumulator plant species Sedum alfredii. Plant Physiol. 2011, 157, 1914-1925. [CrossRef] [PubMed]

144. He, J.; Qin, J.; Long, L.; Ma, Y.; Li, H.; Li, K.; Jiang, X.; Liu, T.; Polle, A.; Liang, Z.; et al. Net cadmium flux and accumulation reveal tissue-specific oxidative stress and detoxification in Populus $\times$ canescens. Physiol. Plant. 2011, 143, 50-63. [CrossRef]

145. Watanabe, M.; Suzuki, T. Involvement of reactive oxygen stress in cadmium-induced cellular damage in Euglena gracilis. Comp. Biochem. Physiol. Part C Toxicol. Pharmacol. 2002, 131, 491-500. [CrossRef]

146. Cuypers, A.; Plusquin, M.; Remans, T.; Jozefczak, M.; Keunen, E.; Gielen, H.; Opdenakker, K.; Nair, A.R.; Munters, E.; Artois, T.J.; et al. Cadmium stress: An oxidative challenge. Biometals 2010, 23, 927-940. [CrossRef]

147. Jedelská, T.; Kraiczová, V. Šmotková; Berčíková, L.; Činčalová, L.; Luhová, L.; Petřivalský, M. Tomato Root Growth Inhibition by Salinity and Cadmium Is Mediated By S-Nitrosative Modifications of ROS Metabolic Enzymes Controlled by S-Nitrosoglutathione Reductase. Biomolecues 2019, 9, 393. [CrossRef]

148. Qiu, R.L.; Zhao, X.; Tang, Y.T.; Yu, F.M.; Hu, P.J. Antioxidative response to Cd in a newly discovered cadmium hyperaccumulator, Arabis paniculata F. Chemosphere 2008, 74, 6-12. [CrossRef]

149. Zhang, C. The Physiological and Biochemical Response of Perennial Ryegrass to Cadmium Stress and the Regulation Effect of Exogenous Calcium Treatment. Master's Thesis, Sichuan Agricultural University, Wenchuan, China, 2018.

150. Deng, G.; Li, M.; Li, H.; Yin, L.; Li, W. Exposure to cadmium causes declines in growth and photosynthesis in the endangered aquatic fern (Ceratopteris pteridoides). Aquat. Bot. 2014, 112, 23-32. [CrossRef] 
151. Lian, J.; Wu, J.; Zeb, A.; Zheng, S.; Ma, T.; Peng, F.; Tang, J.; Liu, W. Do polystyrene nanoplastics affect the toxicity of cadmium to wheat (Triticum aestivum L.)? Environ. Pollut. 2020, 263, 114498. [CrossRef] [PubMed]

152. Gill, S.S.; Tuteja, N. Reactive oxygen species and antioxidant machinery in abiotic stress tolerance in crop plants. Plant Physiol. Biochem. 2010, 48, 909-930. [CrossRef] [PubMed]

153. Zhang, Q.; Lu, L.M.; Dai, Q.X.; Zhu, L.X.; Zheng, H.Y. Cadmium-induced Peroxidation and Production of Sulfur-related Complex in Roots of Narcissuss tazeta var. chinesis. Fujian J. Agric. Sci. 2016, 31, 585-591.

154. Yang, J.R.; He, J.Q.; Zhang, G.X.; Mao, X.Q. The response of several enzyme activities in different tolerant crops to Cd stress. China Environ. Sci. 1996, 113, 117.

155. Sabehat, A.; Lurie, S.; Weiss, D. Expression of small heat-shock proteins at low temperatures. A possible role in protecting against chilling injurie. Plant Physiol. 1998, 117, 651-658. [CrossRef]

156. Rodríguez-Serrano, M.; Romero-Puertas, M.C.; Pazmiño, D.M.; Testillano, P.S.; Risueño, M.C.; del RiíoL, A.; Sandalio, L.M. Cellular response of pea plants to cadmium toxicity: Cross talk between reactive oxygen species, nitric oxide, and calcium. Plant Physiol. 2009, 150, 229-243. [CrossRef]

157. Cai, S.-Y.; Zhang, Y.; Xu, Y.-P.; Qi, Z.-Y.; Li, M.-Q.; Ahammed, G.J.; Xia, X.-J.; Shi, K.; Zhou, Y.-H.; Reiter, R.J.; et al. HsfA1a upregulates melatonin biosynthesis to confer cadmium tolerance in tomato plant. J. Pineal Res. 2017, 62, e12387. [CrossRef] [PubMed]

158. Chen, S.; Yu, M.; Li, H.; Wang, Y.; Lu, Z.; Zhang, Y.; Liu, M.; Qiao, G.; Wu, L.; Han, X.; et al. SaHsfA4c From Sedum alfredii Hance Enhances Cadmium Tolerance by Regulating ROS-Scavenger Activities and Heat Shock Proteins Expression. Front. Plant Sci. 2020, 11, 142. [CrossRef] [PubMed]

159. Zhao, C.; Peng, C.; Wang, P.; Fang, S.G.; Yan, L.L.; Qiu, L.H. Identification of co-chaperone Cdc37 in Penaeus monodon: Coordination with Hsp90 can reduce cadmium stress-induced lipid peroxidation. Ecotoxicol Environ. Safe 2021, 209, 111800. [CrossRef]

160. Shim, D.; Hwang, J.U.; Lee, J.; Lee, S.; Choi, Y.; An, G.; Martinoia, E.; Lee, Y. Orthologs of the class A4 heat shock transcription factor HsfA4a confer cadmium tolerance in wheat and rice. Plant Cell 2009, 21, 4031-4043. [CrossRef] [PubMed]

161. Liu, Y.; Tao, Q.; Li, J.; Guo, X.; Luo, J.; Jupa, R.; Liang, Y.; Li, T. Ethylene-mediated apoplastic barriers development involved in cadmium accumulation in root of hyperaccumulator Sedum alfredii. J. Hazard. Mater. 2021, 403, 123729. [CrossRef] [PubMed]

162. Schellingen, K.; Van Der Straeten, D.; Vandenbussche, F.; Prinsen, E.; Remans, T.; Vangronsveld, J.; Cuypers, A. Cadmium-induced ethylene production and responses in Arabidopsis thaliana rely on ACS2 and ACS6 gene expression. BMC Plant Biol. 2014, 14, 214. [CrossRef] [PubMed]

163. Kong, X.; Li, C.; Zhang, F.; Yu, Q.; Gao, S.; Zhang, M.; Tian, H.; Zhang, J.; Yuan, X.; Ding, Z. Ethylene promotes cadmiuminduced root growth inhibition through EIN3 controlled XTH33 and LSU1 expression in Arabidopsis. Plant Cell Environ. 2018, 41, 2449-2462. [CrossRef]

164. Fuhrer, J. Ethylene Biosynthesis and Cadmium Toxicity in Leaf Tissue of Beans (Phaseolus vulgaris L.). Plant Physiol. 1982, 70, 162-167. [CrossRef]

165. Wang, Y.; Yuan, M.; Li, Z.; Niu, Y.; Jin, Q.; Zhu, B.; Xu, Y. Effects of ethylene biosynthesis and signaling on oxidative stress and antioxidant defense system in Nelumbo nucifera G. under cadmium exposure. Environ. Sci. Pollut. Res. 2020, 27, 40156-40170. [CrossRef]

166. Abozeid, A.; Ying, Z.; Lin, Y.; Liu, J.; Zhang, Z.; Tang, Z. Ethylene Improves Root System Development under Cadmium Stress by Modulating Superoxide Anion Concentration in Arabidopsis thaliana. Front. Plant Sci. 2017, 8, 253. [CrossRef]

167. Jia, X.; Zhao, Y.H.; Liu, T.; He, Y.H. Leaf defense system of Robinia pseudoacacia L. seedlings exposed to 3years of elevated atmospheric CO (2) and Cd-contaminated soils. SCI Total Environ. 2017, 605-606, 48-57. [CrossRef]

168. Li, X.; Zhang, X.; Wu, Y.; Li, B.; Yang, Y. Physiological and biochemical analysis of mechanisms underlying cadmium tolerance and accumulation in turnip. Plant Divers. 2018, 40, 19-27. [CrossRef] [PubMed]

169. Hayat, S.; Hayat, Q.; Alyemeni, M.N.; Ahmad, A. Proline enhances antioxidative enzyme activity, photosynthesis and yield of Cicer arietinum L. exposed to cadmium stress. Acta Bot. Croat. 2013, 72, 323-335. [CrossRef]

170. Zouari, M.; Ben Ahmed, C.; Zorrig, W.; Elloumi, N.; Rabhi, M.; Delmail, D.; Ben Rouina, B.; Labrousse, P.; Ben Abdallah, F. Exogenous proline mediates alleviation of cadmium stress by promoting photosynthetic activity, water status and antioxidative enzymes activities of young date palm (Phoenix dactylifera L.). Ecotoxicol. Environ. Saf. 2016, 128, 100-108. [CrossRef] [PubMed]

171. Zouari, M.; Ben Ahmed, C.; Elloumi, N.; Bellassoued, K.; Delmail, D.; Labrousse, P.; Ben Abdallah, F.; Ben Rouina, B. Impact of proline application on cadmium accumulation, mineral nutrition and enzymatic antioxidant defense system of Olea europaea L. cv Chemlali exposed to cadmium stress. Ecotoxicol. Environ. Saf. 2016, 128, 195-205. [CrossRef]

172. Ali, N.; Hadi, F. Phytoremediation of cadmium improved with the high production of endogenous phenolics and free proline contents in Parthenium hysterophorus plant treated exogenously with plant growth regulator and chelating agent. Environ. Sci. Pollut. Res. 2015, 22, 13305-13318. [CrossRef]

173. Zhou, J.; Cheng, K.; Huang, G.; Chen, G.; Zhou, S.; Huang, Y.; Zhang, J.; Duan, H.; Fan, H. Effects of exogenous 3-indoleacetic acid and cadmium stress on the physiological and biochemical characteristics of Cinnamomum camphora. Ecotoxicol. Environ. Saf. 2020, 191, 109998. [CrossRef]

174. Rady, M.M.; Hemida, K.A. Modulation of cadmium toxicity and enhancing cadmium-tolerance in wheat seedlings by exogenous application of polyamines. Ecotoxicol Environ. Safe 2015, 119, 178-185. [CrossRef] 
175. Alyemeni, M.N.; Ahanger, M.A.; Wijaya, L.; Alam, P.; Bhardwaj, R.; Ahmad, P. Selenium mitigates cadmium-induced oxidative stress in tomato (Solanum lycopersicum L.) plants by modulating chlorophyll fluorescence, osmolyte accumulation, and antioxidant system. Protoplasma 2018, 255, 459-469. [CrossRef]

176. Jiang, H.P.; Gao, B.B.; Li, W.H.; Zhu, M.; Zheng, C.F.; Zheng, Q.S.; Wang, C.H. Physiological and biochemical responses of Ulva prolifera and Ulva linza to cadmium stress. Sci. World J. 2013, 2013, 289537. [CrossRef]

177. Amri, B.; Khamassi, K.; Ali, M.B.; Jaime, A.; Teixeira, S.; Leila, B.B.K. Effects of gibberellic acid on the process of organic reserve mobilization in barley grains germinated in the presence of cadmium and molybdenum. S. Afr. J. Bot. 2016, 106, 35-40. [CrossRef]

178. Mihoub, A.; Chaoui, A.; El, F.E. Biochemical changes associated with cadmium and copper stress in germinating pea seeds (Pisum sativum L.). C R Biol. 2005, 328, 33-41. [CrossRef] [PubMed] 